\title{
Dual Allegiance: Federal and State Treason Prosecutions, the Treason Clause, AND THE FourTeENTH AMENDMENT
}

\author{
ALEXANDER GOUZOULES ${ }^{*}$
}

"For if the crime of high-treason be indeterminate, this alone is sufficient to make the government degenerate into arbitrary power." - Montesquieu ${ }^{1}$

"You know what we used to do in the old days ... [w]ith spies and treason, right? We used to handle them a little differently than we do now." - Donald Trump ${ }^{2}$

\section{INTRODUCTION}

Few accusations carry as much weight as treason, the only crime defined in the Constitution. To Blackstone, it was "the highest civil crime which (considered as a member of the community) any man can possibly commit." ${ }^{\prime 3}$ Under English law in force at the time of the American Revolution, it was punishable by unique, medieval forms of execution. ${ }^{4}$ Modern commentators have described it as "betrayal on the grandest scale possible" and an offense that "still sits atop the criminal pyramid and imposes a stigma unmatched by other crimes."

Treason is also a crime that defies precise definition and raises unique concerns. The founders of the country were unquestionably guilty of treason when they took up arms against King George III and solicited French aid against the English army. ${ }^{7}$ They believed, as did Blackstone ${ }^{8}$ and Montesquieu, ${ }^{9}$ that treason charges were susceptible to misuse by arbitrary and despotic

* J.D., cum laude, Harvard Law School, 2014; M.A., Stanford University, 2011; B.A., Emory University, 2008.

1. Charles de Secondat, Baron de Montesquieu, The Spirit of Laws 139 (J.V. Prichard eds., Thomas Nugent trans., G. Bell \& Sons 1914) (1748).

2. 'Spies and Treason': Read a Transcript of Trump's Remarks Related to the WhistleBlower, N.Y. Times (Sept. 26, 2019), https:/www.nytimes.com/2019/09/26/us/politics/trumptreason-spies-whistle-blower.html [https://perma.cc/S44D-XD22] (last visited Mar. 19, 2020).

3. 4 William BLackstone, COMmENTARIES ON THE LAW OF ENGLAND *76(William Carey Jones ed., 1916).

4. Id. at*93-94; see also Baze v. Rees, 553 U.S. 35, 95-96 (2008) (Thomas, J., concurring).

5. B. Mitchell Simpson III, Treason and Terror: A Toxic Brew, 23 Roger WiLliams U. L. REV. 1, 5 (2018).

6. J. Taylor McConkie, State Treason: The History and Validity of Treason Against Individual States, 101 Ky. L.J. 281, 282 (2013).

7. Cramer v. United States, 325 U.S. 1, 14 (1945) (stating that "[e]very step in the great work of [the founding fathers'] lives from the first mild protests . . . to the final act of separation had been taken under the threat of treason charges").

8. Blackstone, supra note 3 , at *76.

9. MonTESQuieU, supra note 1 , at 139. 
governments. Because of the dangers posed by potential abuse of the charge, the framers of the Constitution thus drafted the Treason Clause to precisely define the crime and protect the rights of those accused of it. ${ }^{10}$ The clause first establishes the scope of the crime and forbids legislative or judicial expansion: "Treason against the United States, shall consist only in levying War against them, or in adhering to their Enemies, giving them Aid and Comfort." It then creates a procedural right that would have fit as naturally within the Bill of Rights as it does within Article III: "No Person shall be convicted of Treason unless on the Testimony of two Witnesses to the same overt act, or on Confession in open Court." "Finally, the clause prohibits "Corruption of the Blood," an archaic term for the penalty through which the individual convicted of treason would lose the ability to inherit or pass property. ${ }^{12}$

But like the Bill of Rights, prior to the passage of the Fourteenth Amendment, the Treason Clause applied only to the federal government. While only the federal government may bring a charge for treason against the United States, individuals may also be charged with treason against states to which they owe allegiance. ${ }^{13}$ Such cases have received little scholarly attention, yet the development of federal treason law cannot be fully understood without an understanding of the state cases.

The first section of this article outlines the history of American treason prosecutions, emphasizing the under-examined state cases and weaving together the parallel bodies of state and federal treason law. Doing so will update and contribute to the existing scholarship on state treason. The seminal work on federal treason remains James Willard Hurst's The Law of Treason in the United States, last revised in 1971. ${ }^{14}$ As Carlton Larson noted in his article on treason and the War on Terror, apart from Hurst's work, "there is virtually no scholarship engaging doctrinal issues in American treason law." "15

10. U.S. Const. art. III, § 3; see The Federalist No. 43 (James Madison) (“[A]s newfangled and artificial treasons have been the great engines by which violent factions, the natural offspring of free government, have usually wreaked their alternate malignity on each other, the convention have, with great judgment, opposed a barrier to this peculiar danger, by inserting a constitutional definition of the crime, fixing the proof necessary for conviction of it, and restraining the Congress, even in punishing it, from extending the consequences of guilt beyond the person of its author.").

11. U.S. CONST. art. III, $\S 3$.

12. U.S. CONST. art. III, § 3; Corruption of Blood, BLACK's LAW DiCtionary (11th ed. 2019).

13. Gilbert v. Minnesota, 254 U.S. 325, 342 (1920) (Brandeis, J. dissenting).

14. James Willard Hurst, The Law of Treason in the United States (1971). Several works published before Hurst's focused on early American cases. E.g., BRADLEY CHAPIN, THE American LaW of Treason: Revolutionary \& EARly National Origins (1964); Richard Z. Steinhaus, Treason, A Brief History with Some Modern Applications, 22 BrooK. L. Rev. 254 (1956); Hayes McKinney, Treason Under the Constitution of the United States, 12 ILL. L. REV. 381 (1918).

15. Carlton F.W. Larson, The Forgotten Constitutional Law of Treason and the Enemy 
In more recent years, James Wilson has argued that a modern death sentence for treason would violate the Eighth Amendment. ${ }^{16}$ George Fletcher has examined how the feudal origins of the treason charge comport with liberal theories of criminal justice. ${ }^{17}$ Several authors have examined the applicability of the treason charge to cases arising out of the 9/11 attacks, the War on Terror, and modern cyber-security issues. ${ }^{18}$ Virtually unique among treason scholarship because of its focus on state charges is J. Taylor McConkie's article, which concludes that state treason charges remain viable today. ${ }^{19}$

This article identifies and attempts to correct various historical omissions that have entered into the existing scholarship, ${ }^{20}$ popular media, ${ }^{21}$ and judicial

Combatant Problem, 154 U. PA. L. REV. 863, 866 (2006).

16. James G. Wilson, Chaining the Leviathan: The Unconstitutionality of Executing Those Convicted of Treason, 45 U. PITT. L. REV. 99, 129 (1983).

17. George P. Fletcher, Ambivalence About Treason, 82 N.C. L. REV. 1611, 1622 (2004).

18. See, e.g., Randal John Meyer, The Twin Perils of the al-Aulaqi Case: The Treason Clause and the Equal Protection Clause, 79 BrooK. L. Rev. 229 (2013); see, e.g., Larson, supra note 15; see, e.g., Henry Mark Holzer, Why Not Call It Treason? From Korea to Afghanistan, 29 S.U. L. Rev. 181 (2002); see, e.g., Suzanne Kelly Babb, Fear and Loathing in America: Application of Treason Law in Times of National Crisis and the Case of John Walker Lindh, 54 Hastings L.J. 1721 (2003); see, e.g., Tom W. Bell, Treason, Technology, and Freedom of Expression, 37 ARIZ. ST. L.J. 999 (2005); see, e.g., Paul T. Crane, Did the Court Kill the Treason Charge?: Reassessing Cramer v. United States and its Significance, 36 FlA. St. U. L. REV. 635, 636 (2009) (discussing prosecution of al-Qaeda operative Azzam al-Amriki); see, e.g., J. Richard Broughton, The Snowden Affair and the Limits of American Treason, 3 L.M.U. L. REV. 5, 6-7 (2015).

19. McConkie, supra note 6.

20. For example, Larson wrote that the Brown treason case "might be read for the proposition that, with respect to the issue of treason against a state, mere presence in the state [rather than citizenship] is sufficient to create liability for treason." Larson, supra note 15, at 889-90. But two of Brown's codefendants were acquitted due to their lack of citizenship. See AmERICAN STATE TRIALS, infra note 122. McConkie wrote that, since ratification, "state courts have completed only two treason prosecutions." McConkie, supra note 6, at 282. This omits cases against several of John Brown's followers (some acquitted on doctrinal grounds and others convicted), as well as William Blizzard, convicted of treason against West Virginia. "The United Mine Workers in West Virginia," infra note 222. McConkie also characterized Lynch as the only decision involving adhering to a state's enemies. McConkie, supra note 6, at 314. However, the Harper's Ferry cases did as well. Hinton, infra note 120. Meyer wrote that the "Supreme Court has consistently held that the prosecution of criminals without the procedural and substantive protections of the Treason Clause under a crime that is substantively treason, but differently named, is an unconstitutional prosecution for a constructive treason offense," citing Cramer, 325 U.S. at 45. Meyer, supra note 18, at 235. However, this over-reading of dicta cannot be reconciled with United States v. Rosenberg, 195 F.2d 583 (2d Cir. 1952).

21. E.g., Kat Eschner, Iva d'Aquino Toguri Remains the Only U.S. Citizen Convicted of Treason Who has Ever Been Pardoned, Smithsonian Magazine, Jan. 29, 2017, President Adams issued a pardon for a treason conviction arising out of an excise tax revolt. See Case of Fries, infra note 70 . 
opinions. ${ }^{22}$ It also identifies three general trends that characterize the majority of federal and state treason prosecutions: (1) heightened evidentiary standards imposed by the federal Constitution and most state constitutions, (2) widespread public sympathy for the accused in marginal cases, and (3) a tendency for executives to grant pardons or commute sentences. Each of these three trends is likely to dissuade prosecutors from pursuing treason charges in close cases, which comports with the purpose of the Treason Clause and the intentions of its framers.

In the next section, this article examines the current status of state treason law, as some contemporary authors have questioned whether the charge remains viable. ${ }^{23}$ Such uncertainties are partially a product of literature that has consistently overlooked several state treason prosecutions, ${ }^{24}$ thus portraying others as more aberrational than they truly were. Given the existing body of precedent from several states, the theoretical viability of state treason cannot reasonably be questioned. ${ }^{25}$ I also analyze whether state and federal treason charges have any practical relevance today, proposing that the decline in modern treason prosecutions is not driven by cultural hesitation as to "whether and how we should punish it," ${ }^{26}$ as George Fletcher has suggested. Instead, the three trends identified above have rendered the charge disfavored by prosecutors, who can obtain convictions and harsh sentences for lesser crimes of disloyalty (such as espionage or seditious conspiracy) against offenders whose conduct is colloquially referred to as "treasonous."

This article presents a case for a partial revival of treason law, accompanied by a de-emphasis on other disloyalty offenses, because the treason charge, with its accompanying constitutional and practical limitations, has historically resulted

22. Inexplicably, the Supreme Court stated in a 1976 footnote that "[i]t appears that no one has ever been prosecuted under these or other state treason laws." Woodson v. North Carolina, 428 U.S. 280, 292 n.25 (1976). As discussed throughout this article, state treason prosecutions have permeated American history, and several men have been executed for state treason - in fact more than for federal treason. In Cramer v. United States, the Supreme Court stated that, "[i]n the century and a half of our national existence not one execution on a federal treason conviction has taken place.” 325 U.S. at 24. In fact, William Bruce Mumford was executed during the Civil War for treason, in what contemporary newspapers described as "the first instance in the history of our country where a man has received the punishment of death for treason." Particulars of the Execution of William B. Mumford for Hauling Down the U.S. Flag, N.Y. HeRALD, June 19, 1862, at 1, https://chroniclingamerica.loc.gov/lccn/sn83030313/1862-06-19/ed-1/seq-1/ [https://perma. cc/64AD4-79KE].

23. E.g., Larson, supra note 15, at 886 ("Whether treason against an individual state was or is a viable crime is a fascinating question, but one that lies beyond the scope of this Article.").

24. For example, both Hurst, the preeminent American scholar of treason, and McConkie, one of the few authors to focus on state charges, omit West Virginia's treason cases arising out of the Blair Mountain labor action. See generally Brandon Nida, Demystifying the Hidden Hand: Capital and the State at Blair Mountain, 47 HIST. ARCH. 52, 63 (2013); see also McConkie, supra note 6; see also Hurst, supra note 14.

25. See generally McConkie, supra note 6.

26. Fletcher, supra note 17, at 1612. 
in a better balance between the security interests of the state and the civil liberties of the accused. The following analysis of state treason law, however, demonstrates that prosecutions for state treason could be (and have been) undertaken for conduct falling beyond the scope of the federal Constitution's Treason Clause. In the article's conclusion, I suggest that this outcome is improper under the modern constitutional doctrine of incorporation.

Through the doctrine of incorporation, the Supreme Court has held that virtually all individual rights set forth in the Bill of Rights apply against the states through the Fourteenth Amendment. To determine whether any particular right is incorporated against the states, the Court has analyzed whether that right is "'fundamental to our scheme of ordered liberty,' or 'deeply rooted in this Nation's history and tradition." ${ }^{27}$ This article's review of the history of federal and state treason law in the United States leads to the conclusion that the Treason Clause should be incorporated against the states according to this standard.

To the best of my knowledge, this argument is novel, and it has implications outside of criminal law, such as whether other sections of the pre-1868 Constitution should be incorporated through the Fourteenth Amendment.

\section{ENFORCING ALLEGIANCE TO TwO SOVEREIGNS: THE HISTORY OF TREASON PROSECUTIONS AT THE STATE AND FEDERAL LEVEL}

\section{A. "To Take Out of the Hands of Tyrannical Kings ... that Deadly Weapon": Treason in English and Colonial Law}

The statutory definition of treason in English law can be traced back to $1351 .^{28}$ The Treason Act of that year established seven categories of high treason, including levying war and adhering to the king's enemies, as well as imagining the death of the king, improper relations with the king's companion or daughter, counterfeiting royal documents or currency, and murdering royal officials. ${ }^{29}$ It also defined petit treason, a crime which prohibited the violation of feudal hierarchies: "when a servant slayeth his master, or a wife her husband, or when a man secular or religious slayeth his prelate. ..."30

Although this codification ostensibly fixed the definition of the crime, the scope of treason prosecutions in England expanded in subsequent centuries. ${ }^{31}$ Broader, judicially constructed definitions of treason came to encompass attempts to prevent the application of a lawful statute. ${ }^{32}$ Charges of "compassing the king's death" were used to suppress political dissent, ${ }^{33}$ and applications of treason law

27. Timbs v. Indiana, 139 S. Ct. 682, 686-87 (2019) (quoting McDonald v. City of Chicago, 561 U.S. 742, 767 (2010)).

28. Treason Act 1351, 25 Edw. 3, Stat 5 (Eng.).

29. Id.

30. Id.

31. Bradley Chapin, The American Law of Treason 3-7 (1964).

32. Id.

33. HuRST, supra note 14 , at 5. 
widened to the point of absurdity. Henry VIII made it treason for anyone to refuse to take an oath acknowledging his children with Anne Boleyn as legitimate heirs to the throne; ${ }^{34}$ he later made it treason for anyone to claim that his children with Anne had been legitimate. ${ }^{35}$ In 1663, a man was convicted of treason for publishing a tract suggesting that the king was accountable to the people. ${ }^{36}$

In light of the subsequent misuse of the treason charge, the relatively narrow English Treason Act of 1351 was held in high regard by American colonists. Indeed, it was believed to be a cornerstone of English liberties, alongside cherished documents such as the Magna Carta. ${ }^{37}$ In his influential Commentaries on the Laws of England, Blackstone recognized the importance of limiting the outer bounds of the treason charge by statute:

[B]y the ancient common law, there was a great latitude left in the breast of the judges, to determine what was treason, or not so: whereby the creatures of tyrannical princes had opportunity to create [an] abundance of constructive treasons; that is, to raise, by forced and arbitrary constructions, offenses into the crime and punishment of treason which never were suspected to be such. ${ }^{38}$

Similarly, in his Spirit of Laws, Montesquieu wrote that, if "the crime of hightreason be indeterminate, this alone is sufficient to make the government degenerate into arbitrary power." ${ }^{\prime 39}$

The earliest treason prosecutions in the American colonies were conducted either under martial law or, in the puritan colonies of New England, according to law derived from biblical citations. ${ }^{40}$ But by the late seventeenth century, the colonies began to enact treason statutes that drew substantive content from the English Treason Act of 1351 and procedural requirements from the English Treason Trials Act of 1688, which required the testimony of two witnesses to an overt act for a treason conviction. ${ }^{41}$ Treason law nonetheless remained fluid, and expansive definitions were adopted in times of emergency, such as during colonial wars with France or periods of domestic unrest. ${ }^{42}$ The charge of petit treason, the common-law offense of violating feudal hierarchies, was also deployed against slaves who killed whites in the colonies. ${ }^{43}$ But all told, treason

34. Act Respecting the Oath to the Succession 1534, 26 Hen. 8 c. 2 (Eng.).

35. Second Succession Act 1536, 28 Hen. 8 c.7 (Eng.).

36. CHAPIN, supra note 31 , at 4.

37. Larson, supra note 15 , at 870-71.

38. Blackstone, supra note 3 , at $* 76$. For discussion of how the Act was viewed by early English treatises, see HuRst, supra note 14, at 16-28.

39. Montesquieu, supra note 1 , at 139.

40. HuRST, supra note 14, at 68-70.

41. Id. at 71-72; CHAPIN, supra note 31, at 6 .

42. ChapIn, supra note 31, at 6-9; HuRSt, supra note 14, at 79.

43. See 11 American State Trials 511-12 (John D. Lawson ed., 1919) (“The Trial of Mark and Phillis (Negro Slaves) For Petit Treason, In the Murder of Captain John Codgman, Their Master, Cambridge Massachusetts, 1755"). The offense carried a harsher method of execution at 
prosecutions of any type were rare, and a settled common law of treason did not develop during the colonial period. ${ }^{44}$

The Revolutionary War would permanently alter the substantive law of treason in America. As Justice Jackson would later write, "[m] any a citizen in a time of unsettled and shifting loyalties was . . . threatened under English law which made him guilty of treason if he adhered to the government of his colony and also under colonial law which made him guilty of treason if he adhered to his King. ${ }^{\text {" }}$ Although the British regarded revolutionary colonists as traitors, the threat of reprisals against British prisoners of war prevented them from executing those they captured - at least while the war was ongoing. ${ }^{46}$ Parliament thus suspended the writ of habeas corpus, providing for indefinite detention of accused colonial traitors during the course of the war. ${ }^{47}$ They likely would have faced treason prosecutions and certain convictions had the British prevailed. ${ }^{48}$

On the American side, the Continental Congress's Committee on Spies recommended that each colony enact a new law punishing treason, which it defined as:

all persons, members of, or owing allegiance to any of the United Colonies ... who shall levy war against any of the said colonies within the same, or be adherent to the king of Great Britain, or others the enemies of the said colonies, or any of them, within the same, giving to him or them aid and comfort . .."49

All colonies apart from Georgia enacted a treason statute. ${ }^{50}$ The colonies' formal criminalization of treason was deeply significant, as it constituted a demand for allegiance from citizens that was, in itself, a declaration of independence. ${ }^{51}$ Their

common law than murder: it could entail burning at the stake. See id.

44. HuRst, supra note 14 , at 68 . The only colonial prosecution for high treason of which a significant record remains took place in New York in 1702 and involved a power struggle between rival factions in the colony while awaiting the arrival of a new governor from England. See Cramer v. United States, 325 U.S. 1, 12 n.16 (1945); American State Trials, supra note 43, vol. 10, at 518-20 ("The Trial of Nicholas Bayard for High Treason"). The defendant was charged after petitioning the king to remove the current lieutenant governor, and he argued in his defense that "there was no treason in exercising the right of petition for the redress of grievances." Id. at 520 . The prosecution was controversial: the Attorney General refused to take part, and the Chief Justice "practically forced a verdict of guilty from an unwilling jury." Id. The defendant was sentenced to be drawn and quartered, according to the mandatory sentence at the time. Id. Fortunately, the sentence was never carried out, and the prisoner was released upon the arrival of the colony's new governor. $I d$.

45. Cramer, 325 U.S. at 11-12.

46. CHAPIN, supra note 31 , at 25-28.

47. Id.

48. Id.

49. See HuRst, supra note 14 , at 84 .

50. Willard Hurst, Treason in the United States, 58 HARV. L. REv. 226, 248 n.35 (1944).

51. CHAPIN, supra note 31 , at 115. 
victory ensured that the revolutionaries' actions would not be prosecuted as treason by the British.

The Articles of Confederation contained no mechanism for punishing treason against the United States, nor did they establish any national courts competent to hear such a charge. ${ }^{52}$ The individual states thus bore the responsibility of prosecuting treason against the new nation. ${ }^{53}$ But as the Articles proved inadequate and the nation formed a centralized national government, whether disloyalty to that government would be punished as treason needed to be addressed.

Surely on the minds of the delegates to the Constitutional Convention was the fact that, but for their victory, many of them would have faced treason charges. Also on their minds was the importance of the Treason Act of 1351 to the system of English liberty. As Jefferson noted, that statute "has expressed and defined all treasonable offences . . . and that this was done to take out of the hands of tyrannical Kings, and of weak and wicked Ministers, that deadly weapon, which constructive treason had furnished them with ...."54 The convention wasted little time in inserting a restrictive treason clause into early drafts of the Constitution..$^{55}$

From its initial draft, the clause defined treason only as levying war or in adhering to the nation's enemies, thus significantly narrowing the scope of high treason and eliminating petit treason. ${ }^{56}$ Some of the framers, including James Madison, argued that the clause was overly restrictive, unnecessarily limiting the crime even further than the Treason Act of 1351 had. ${ }^{57}$ The restrictive view nevertheless won the day, and the Convention also added a more burdensome evidentiary limitation than the one found in the Treason Trials Act of 1688: Two witnesses must testify to the same overt act in open court to obtain a conviction. ${ }^{58}$ In arguing for this addition, Franklin noted that "[p]rosecutions for treason were generally virulent; and perjury too easily made use of against innocence." Though James Wilson noted that this requirement might make it more difficult to punish, for example, "carrying on a treasonable and treacherous

52. The Articles did require states to return fugitives accused of treason to the state in which they had been accused. See ARTICles of CONFEDERATION OF 1781, art. IV, para. 2.

53. People v. Lynch, 11 Johns 549, 553 (N.Y. 1814) ("Under the old confederation, there was no judicial power organized, and clothed with authority for the trial and punishment of treason against the United States of America. It became necessary, therefore, to provide for it under the judicial powers of the several states ...").

54. HuRst, supra note 14 , at 85-86.

55. Id. at 86 .

56. Id. at 87 .

57. Max Farrand, Records of the Federal Convention, vol. 2, Aug. 20, 1787 ("Mr. Madison thought the definition too narrow. It did not appear to go as far as the Statute of Edward the Third. He did not see why more latitude might not be left to the Legislature. It would be as safe as in the hands of State Legislatures; and it was inconvenient to bar a discretion which experience might enlighten, and which might be applied to good purposes as well as be abused.”)

58. Id.; HuRST, supra note 14, at 133-34.

59. FARRAND, supra note 57. 
correspondence with an Enemy," he nonetheless voted for the enhanced evidentiary standard, which was adopted. ${ }^{60}$

But what would become of state treason laws? Critically, the Convention rejected an attempt to define treason solely at the national level. The original draft of the Treason Clause would have established that "treason against the United States shall consist only in levying war against the United States, or any of them; and in adhering to the enemies of the United States, or any of them." ${ }^{\prime 1}$ Under this wording, the crime of treason against a state government would have become redundant with treason against the United States. Gouverneur Morris argued that the federal government should have "an exclusive right to declare what should be treason," because in a "contest between the United States and a particular state," the people should owe allegiance to only one authority. ${ }^{62}$

But William Johnson and James Wilson moved to strike the words "or any of them." ${ }^{63}$ Johnson argued that treason against a state government was impossible, as the federal government would be the supreme sovereign under the proposed system. ${ }^{64}$ In opposing Morris's wording, they were joined by George Mason for a different reason; Mason argued that the United States would "have a qualified sovereignty only" and that an act could be treason against a state government that would not be treason against the United States. ${ }^{65}$ Mason's view prevailed: the final form of the clause did not include "or any of them," and state treason remained a viable crime - despite Madison expressing concern that an offender might be subject to punishment by both a state and federal government for the same act. ${ }^{66}$

Those who drafted the Treason Clause considered it to be of critical importance. James Wilson in particular praised the protections it provided to Americans as superior to those provided in England, as the "citizens of the Union are secured effectually from even legislative tyranny: and in this instance, as in many others, the happiest and most approved example of other times has not only been imitated, but excelled." ${ }^{67}$ In Federalist No. 43, Madison wrote that the Convention "with great judgment . . . insert[ed] a constitutional definition of the crime, fixing the proof necessary for conviction of it, and restraining the Congress, even in punishing it, from extending the consequences of guilt beyond the person of its author." And in Federalist No. 84, Hamilton addressed the criticism that the proposed Constitution contained no Bill of Rights by reference to the Treason Clause.

60. HuRST, supra note 14, at 94.

61. Id. at 129-30 (emphasis added).

62. FARRAND, supra note 57.

63. Id.

64. Id.

65. Id.

66. Id.

67. HuRst, supra note 14, at 136. 


\section{B. "A Qualified Sovereignty Only": State and Federal Treason in the Early Republic}

This new law of federal treason was soon tested. The first trials and convictions arose out of the Whiskey Rebellion and similar acts of resistance to taxes imposed by the new government. ${ }^{68}$ Several Whiskey Rebels were convicted of treason for their role in the brief uprising, though they received pardons from the Washington Administration, as one of the convicted was regarded as "probably insane" and the other "a simpleton." ${ }^{69}$ In 1799, a group of rioters opposed to an excise tax were convicted of treason for "constructive" levying of war against the United States - precisely the type of expansive charge that the framers of the Treason Clause had sought to prohibit. ${ }^{70}$ President John Adams correctly concluded that "their crime did not amount to treason" and pardoned the offenders. ${ }^{71}$

These initial cases set a trend that would be continued in many future treason cases: pardons and commutations in close cases. This trend had been anticipated by Alexander Hamilton, who had argued against requiring Senate approval for a treason pardon. ${ }^{72}$ Hamilton had explained that "there are often critical moments, when a welltimed offer of pardon to the insurgents or rebels may restore the tranquility of the commonwealth." 73

The first major judicial interpretation of the Treason Clause involved former Vice President Aaron Burr. In 1806, Burr entered into a murky conspiracy to create a new nation in the west consisting of lands the conspirators planned to seize from Spain and the United States. ${ }^{74}$ Burr conspired with General James Wilkinson and others, and the group at one point appealed to the British for funds and a naval detachment to support their aims. ${ }^{75}$ Their convoluted plan was to use Wilkinson's troops to launch a border war with Spain, giving them the opportunity to trigger a Creole uprising in newly acquired Louisiana, which they planned to use as a base for the conquest of Spanish Mexico by a private army. ${ }^{76}$ Ultimately, a small force of volunteers assembled on an island on the Ohio River, and Burr planned to join them downriver on a march toward New Orleans. ${ }^{77}$ But Wilkinson betrayed Burr after President Jefferson learned of the conspiracy, and Jefferson promptly caused his former Vice President to be apprehended. ${ }^{78}$

68. Id. at 268 .

69. Id. at 269 .

70. U.S. v. Fries, 9 Fed. Cas. 826, 924 (C.C.D. Pa. 1799); HuRst, supra note 14, at 94, 260.

71. Hurst, supra note 14, at 269.

72. The Federalist No. 74 (Alexander Hamilton).

73. Id.

74. Thomas P. Abernethy, The Burr Conspiracy 10-23 (1954); Chapin, supra note 31, at 98 .

75. ABERNETHY, supra note 74, at 15, 23.

76. See id. at 28-30.

77. See id. at 61-79.

78. See id. at 101-40; CHAPIN, supra note 31, at 99-100. 
Two conspirators, Erick Bollman and Samuel Swartout, were arrested and brought under military guard to the capital. ${ }^{79}$ Jefferson asked the Senate to suspend the writ of habeas corpus, which it duly voted to do. ${ }^{80}$ But the House did not follow suit, giving the prisoners the chance to bring a habeas petition. ${ }^{81}$ Chief Justice Marshall held that the evidence against Bollman and Swartout, who had not taken part in any military formation, was inadequate to prove they had "levied war" against the United States. ${ }^{82}$ Marshall found that, "[t]o complete the crime of levying war against the United States, there must be an actual assemblage of men for the purpose of executing a treasonable design." ${ }^{\prime 3}$ The decision established that conspiracy with the intention to assemble does not constitute treason.

The subsequent trial of Burr was chaotic. ${ }^{84}$ After the Bollman and Swartout acquittals, the prosecution indicted Burr for actual treasonous assembling on the island in the Ohio River - but in fact he had not been present until later. ${ }^{85}$ Thus, the prosecution was forced to argue that Burr had "constructively" been present, based on his participation in the conspiracy. ${ }^{86}$ But the Constitution required two witnesses to an overt act, and there were no witnesses to Burr's joining of a treasonous assembly on the island ${ }^{87}$ Burr was thus spared, demonstrating that the charge of treason would not be expanded, even in disturbing and politically fraught circumstances.

\section{The Post-Burr Era of State Treason Charges}

Every state other than Hawaii either ratified a treason clause in its constitution or enacted a statute defining treason after joining the Union. ${ }^{88}$ The line between these state laws and federal treason was initially blurry. During the War of 1812, a group from New York was charged with treason by that state for selling provisions to a British warship. ${ }^{89}$ The Supreme Court of Judicature of New York dismissed the indictment, holding that, even "admitting the facts charged against the prisoners to amount to treason against the United States, they do not constitute the offense of treason against the people of the state of New-York, as charged in the indictment." 90 The court reasoned that:

The people of this state, as citizens United States, are at war with Great

79. CHAPIN, supra note 31 , at $99-101$.

80. Id.

81. Id.

82. Ex parte Bollman and ex parte Swartwout, 8 U.S. 75, 127, 135 (1807).

83. Id. at 127.

84. The prosecution's key witness, General Wilkinson, was nearly indicted himself by the grand jury. CHAPIN, supra note 31, at 105 .

85. Id. at 98-113.

86. Id.

87. Id

88. McConkie, supra note 6, at 291-93.

89. People v. Lynch, 11 Johns. 549, 552 (N.Y. Sup. Ct. 1814) (italics omitted).

90. Id . at 553 . 
Britain, in consequence of the declaration of war by Congress. The state, in its political capacity, is not at war. The subjects of Great Britain are the enemies of the United States of America, and the citizens thereof, as members of the Union, and not of the State of New-York, is laid in the indictment. $^{91}$

This same reasoning was later accepted by the Supreme Court in a different case. $^{92}$

If state treason charges could not be brought against those adhering to a wartime enemy, what did state treason encompass? One might have expected the state charge to wither away. However, although the next significant federal treason case would not arise until the Civil War, notable state treason prosecutions took place in the intervening period. In these key early years, state jurisprudence would shape the way treason was conceived of in American law.

The first such case arose in Rhode Island, the last state to adopt its own constitution. Rhode Island's General Assembly exercised supreme judicial, executive, and legislative powers pursuant to its original royal charter until the passage of its constitution in $1842 .{ }^{93}$ Only a small fraction of its population could vote. ${ }^{94}$ Reformers called a convention to ratify what would be known as the People's Constitution. ${ }^{95}$ The legislature rejected it, advancing its own, competing constitution. ${ }^{96}$ Contested elections for governor were held in 1842, with the establishment's Samuel Ward King and reformer Thomas Wilson Dorr both claiming victory under the different constitutions. ${ }^{97}$

King proclaimed martial law and sought Dorr's arrest, while a core group of Dorr's supporters tried and failed to seize an arsenal in Providence. ${ }^{98}$ Ultimately, around 140 men assembled under Dorr at Acote's Hill, where they faced off against 4,000 soldiers of the state militia under King. ${ }^{99}$ Dorr's men melted away after a brief confrontation. ${ }^{100}$ Dorr was arrested and charged with treason against Rhode Island. ${ }^{101}$ The prosecution contended that Dorr's appearance "at the head of armed men, and advising them to act, is a levying war. Dispersi[ng] without any actual engagement does not take away the character of treason."102

Dorr's counsel unsuccessfully argued that treason could only be committed

91. Id. (italics omitted).

92. Gilbert v. Minn., 254 U.S. 325, 342 (1920).

93. John Lawson, American State Trials 5 (vol. 2 1914).

94. See id. at 6-7.

95. Id. at 7-8.

96. Id. at $8-9$.

97. Id. at 9-10.

98. Id. at 10-11.

99. Id. at 11 .

100. Id.

101. Id.

102. Id. at 21 . 
against the United States, not against the individual states. ${ }^{103}$ The Rhode Island court rejected this argument. ${ }^{104}$ Dorr's counsel also argued that he did not commit treason because he had been acting under the People's Constitution. ${ }^{105}$ In rejecting this defense, the court explained that the "acts set up by the prisoner . . . were revolutionary in their character, and success was necessary to give them effect."106 Here was a fascinating judicial acknowledgment of the fundamentally political nature of the treason charge: All revolutionaries, including those that founded the country, can be accused of treason. ${ }^{107}$ Guilt lies in a lack of success.

Dorr was convicted by a jury that was handpicked to include only loyalists, and he was sentenced to life in prison. ${ }^{108}$ But his case demonstrates another overarching trend that would apply to later treason convictions: his case drew widespread public sympathy rather than opprobrium. Support for the imprisoned Dorr was such that a "liberation" candidate was elected governor to replace King. ${ }^{109}$ Dorr was released after a year, but his health never recovered from his time in prison. ${ }^{110}$

Two years later, in 1844, Mormon leader Joseph Smith was charged with treason against the state of Illinois. ${ }^{111}$ Smith and his followers entered Illinois after escaping from Missouri, where they had also been charged with state treason in $1838 .{ }^{12}$ In Illinois, the Mormons built the city of Nauvoo and established their own militia. ${ }^{113}$ Illinois public opinion turned against the new city after it passed a resolution calling for destruction of the anti-Mormon press, and Smith was indicted by the state on various charges. ${ }^{114}$ Facing a potential attack from neighboring towns, Smith called out Nauvoo's militia. ${ }^{115}$ He and other leaders were then charged with treason for resisting state authorities by force of arms. ${ }^{116}$

McConkie concluded that the treason charges against Smith "likely would

103. Id. at 71 .

104. Id. at 84-85.

105. Id. at 72 .

106. Id.

107. See United States v. Cramer, 325 U.S. 1, 14 (1945). Despite the magnitude of the offense, most nations consider treason to be a purely political crime for which an offender is not subject to extradition. See Charles L. Cantrell, The Political Offense Exemption in International Extradition: A Comparison of the United States, Great Britain and the Republic of Ireland, 60 MARQ. L. REV. 777, 780 (1977).

108. Lawson, supra note 93, at 12-13.

109. Id. at 13 .

110. Id.

111. HuRST, supra note 14, at 264.

112. $I d$.

113. McConkie, supra note 6 at 310-11; Brent M. Rogers, "Armed men are coming from the state of Missouri": Federalism, Interstate Affairs, and Joseph Smith's Final Attempt to Secure Federal Intervention in Nauvoo, 109 J. ILL. ST. Hist. SoC'y 148, 153 (2016).

114. McConkie, supra note 6 , at 311 .

115. Id.

116. Id. 
have failed due to a lack of treasonous intent and other legal deficiencies." ${ }^{117}$ But Dorr had been convicted despite having an even more persuasive argument that he lacked treasonous intent-Dorr assembled a militia believing he was the legitimate governor of the state. Either way, before a trial could take place, a mob murdered Smith after dragging him from his prison cell. ${ }^{118}$ Smith's successors in the Church of Latter Day Saints would also be charged with federal treason in 1857 after resisting U.S. Army troops in Utah Territory, but they were not brought to trial, as President Buchanan granted a general pardon. ${ }^{119}$ As Hamilton had anticipated, a preemptive pardon ended a potential rebellion.

By far the most historically significant state treason trial was John Brown's in 1859. A deeply committed abolitionist, Brown and his sons had participated in the "Bleeding Kansas" conflict between pro-slavery and abolitionist fighters earlier in the decade. ${ }^{120}$ Several free-state fighters in Kansas had been captured and charged with federal treason (Kansas had yet to achieve statehood and thus was a federally administered jurisdiction), but Brown escaped and began planning a new operation. ${ }^{121}$

Brown aimed to lead a small group of committed followers in a surprise attack on Harper's Ferry, Virginia (now West Virginia), where a large slave population toiled near a lightly defended federal armory. ${ }^{122}$ His plan was to raise and arm a vanguard of freed slaves and abolitionist whites that would operate in the nearby Blue Ridge Mountains, inspiring a broader uprising that would lead to emancipation. ${ }^{123}$ After initially taking the arsenal, Brown's men were defeated. ${ }^{124}$ Six civilians and fifteen of Brown's men (including two of his sons) were killed, and five were taken prisoner. ${ }^{125}$

The prisoners were indicted for treason against the Commonwealth of Virginia. The resulting indictment alleged in part that Brown and his codefendants, Aaron Stevens, Edwin Coppock, Shields Green, and John Copeland:

together with divers[e] other evil-minded and traitorous persons . . not

117. $I d$.

118. Id.

119. David Roberts, The Brink of War, SMITHSOnIAN MAG. (June 2008), https://www.smithsonianmag.com/history/the-brink-of-war-48447228/ [https://perma.cc/9DPSXAS7].

120. See Richard J. Hinton. John Brown and His Men: With Some Account of the RoAds They Traveled to ReAch Harper's Ferry 43-57 (1894).

121. Id. at 58-59 n.1.

122. See John LAwson, The Trial of John Brown for Treason and Insurrection, AMERICAN State Trials 708-12 (vol. 6 1914) (hereafter “Trial of John Brown”); Robert M. De Witt, The Life, Trial, and Execution of Captain John Brown, Known as "Old Brown of Ossawatomie;" with a Full Account of the Attempted Insurrection at Harper's Ferry 29-30 (1859).

123. Trial of John Brown, supra note 122, at 703.

124. De Witt, supra note 122 , at 29

125. Id. at 37-38. 
having the fear of God before their eyes, but being moved and seduced by the false and malignant counsel of other evil and traitorous persons and the instigations of the devil, did ... feloniously and traitorously make rebellion and levy war against the said Commonwealth of Virginia[.] $]^{126}$

They were also charged with inciting a slave rebellion and murder. ${ }^{127}$ When they were brought to trial, Brown and Stevens "were unable to walk, the former having three sword stabs in the body and a sabre cut on the head; the latter had three bullets in his head, two in his breast, and one in his arm, he had the appearance of a dying man and breathed with great difficulty." ${ }^{28}$

As will be analyzed below, Virginia law (then and today) provides a more expansive definition of treason than the Constitution. As the prosecution noted:

[T]reason against the United States consisted only in levying war against them or adhering to their enemies and giving them aid and comfort . . . Yet the State law is more full, and includes within its definition of treason the establishing, without the authority of the Legislature, any Government within its limits, separate from the existing Government, or the holding or executing, under such Government, of any office; professing allegiance or fidelity to it, or resisting the execution of law, under the color of its authority; and it goes on to declare that such treason, if proved by the testimony of two witnesses to the same overt act, or by confession in Court, shall be punished with death. ${ }^{129}$

Despite the fact that Brown was not a Virginia citizen, he was charged with violating each prong of Virginia's treason law. ${ }^{130}$ His counsel unsuccessfully argued that a party cannot be guilty of state treason "unless he be a citizen of the State or Government against which the treason so alleged has been committed."131 The court rejected this argument. ${ }^{132}$

This decision aligned with traditional principles of treason law, which hold that non-citizens present in a state owe allegiance to it unless they entered as part of a military invasion, ${ }^{133}$ though the decision would not align with subsequent

126. Id. at 59-61. The rushed indictment misspelled the names of Brown's men. See Trial of John Brown, supra note 122, at 728. Their correct names are used here.

127. Id.

128. Trial of John Brown, supra note 122, at 725-27.

129. De Witt, supra note 122, at 68.

130. Id. at 87.

131. Id. at 86 .

132. Id.

133. See, e.g., William Hawkins, A Treatise of the Pleas of the Crown: Or a System of the Principal Matters Relating to That Subject, Digested under Their Proper Heads 35 (1716) ("Also it seems clear, [t]hat the subjects of a foreign [p]rince coming into England and living under the protection of our [k]ing, may, in respect of that local [alle]giance which they owe to him, be guilty of [h]igh [t]reason."); see also Larson, supra note 15, at 867 (“Anglo-American 
holdings by the same court. Brown was convicted, sentenced to death, and executed. ${ }^{134}$ Coppock's trial began immediately after Brown's and was largely a repetition of it. ${ }^{135} \mathrm{He}$ too was convicted of treason against Virginia and executed. ${ }^{136}$

Next on trial were Copeland and Green, both of African descent; Copeland was born free, while Green had escaped slavery before joining up with John Brown. ${ }^{137}$ Their counsel convinced the court to dismiss the treason charges against both defendants, on the ground that they owed no allegiance to Virginia. ${ }^{138}$ For support, he cited the infamous Dred $S$ cottl ${ }^{139}$ decision, in which the Supreme Court held that Americans of African descent were not citizens of the United States, and the Virginia court was persuaded. ${ }^{140}$ The court's legal reasoning was muddled by racism: It had just decided that citizenship was irrelevant to allegiance, as neither Brown nor Coppock were citizens of Virginia, yet both had been convicted. The court appears to have concluded that noncitizens Copeland and Green (unlike non-citizens Brown and Coppock) did not "owe allegiance" to the state because of their race alone. ${ }^{141}$ But their legal victory was pyrrhic; both were found guilty of murder and executed after Brown. ${ }^{142}$

Another of Brown's men, John Cook, made a full confession that implicated Brown and was then acquitted of treason; he was nonetheless convicted of murder. ${ }^{143}$ Stevens's case was transferred to federal court, potentially based on the belief by Virginia authorities that a federal court would have jurisdiction to "examin[e] . . . the northern friends and backers of Brown and . . Republic leaders." "144 It was later returned to Virginia state court and joined with the case

law has never held that allegiance is simply a question of citizenship."); but see SANFORD LEVINSON, CONSTITUTIONAL FAith 116 (1988) (treason "can be committed only by a citizen"); Ex parte Quarrier, 2 W. Va. 569, 572 (1866) ("Others may be enemies, but the citizen only may be enemy and traitor also.").

134. De Witt, supra note 122, at 95.

135. John Lawson, The Trial of Edwin Coppoc for Treason, Insurrection, and Murder, American State Trials 806-08 (vol. 6 1914).

136. Id.

137. Id. at 809-13.

138. JoHn LAWSOn, The Trial of John Anthony Copeland and Shields Green for Insurrection and Murder, American State Trials 809-13 (vol. 6 1914) (hereafter "Trial of John Anthony Copeland").

139. Scott v. Sanford, 60 U.S. 393 (1857).

140. Trial of John Anthony Copeland, supra note 138.

141. Id. I have found no other antebellum decision suggesting that only whites could commit treason; indeed, during the colonial period, slaves of African descent were charged with petit treason when they committed murder. See supra note 43.

142. Trial of John Anthony Copeland, supra note 138, at 813.

143. See Richard J. Hinton, supra note 120, at 449-528 (confession); Steven Lubet, John Brown's Spy: The Adventurous Life And Tragic Confession of John E. CoOK 197 (2012) (acquitted of treason).

144. Id. at $817-18 \mathrm{n} .11$. 
of Albert Hazlett, another of Brown's men who had initially escaped the raid but later was captured. ${ }^{145}$ Both were convicted of state treason and hanged on March $16,1860 .^{146}$

Brown, Coppock, Stevens, and Hazlett were the first four men put to death for state or federal treason in the United States. They remain the only men executed for state treason. While they may have been reviled in Virginia, their treason trials generated intense sympathy in the North, ${ }^{147}$ which would soon find itself at war over slavery.

\section{Rebellion and the Revival of Federal Treason}

Brown's actions were a prelude to the Civil War, an unprecedented test for American treason law. Hundreds of Americans who had sworn oaths to defend the United States instead took up arms for the Confederacy. Of the 1,080 officers active in the regular army at the time of secession, 286 resigned or were dismissed and entered Confederate service. ${ }^{148}$ Likewise, of the 900 West Point graduates then in civilian life, 114 returned to the federal army while ninety-nine joined the Confederate army. ${ }^{149}$ At this time of mass disloyalty, no person had been convicted of treason against the United States since the Adams Administration, ${ }^{150}$ and even that conviction had resulted in a pardon from Adams, who deemed it invalid. ${ }^{151}$

It initially appeared that treason prosecutions would play a major role in the conflict, especially in critical border states such as Maryland that were home to many Confederate partisans. ${ }^{152}$ Baltimore rioted when federal troops moved through the city toward Washington, leading to the deaths of four Massachusetts soldiers. ${ }^{153}$ Throughout April of 1861, members of the Baltimore police and the Maryland militia set fire to strategic railroad bridges and telegraph wires leading

145. Id. at $817-18,862-64$.

146. The Vengeance of Virginia, N.Y. Times, Mar. 16, 1860, at 4 ("Virginia, today, will hang two men . . . for treason to an American state."); JoHn LAwson, The Trial of John E. Cook for Treason, Insurrection, and Murder, AMERICAN StATE Trials 862-64 (vol. 6 1914) (Stating that Stevens and Hazlett were executed on March 16, 1860).

147. See, e.g., id.

148. Richard W. Stewart, American Military History, Ctr. of Milit ARy History 202 (vol. 12009 ). Enlisted men proved far more loyal; only 26 left the Union army to fight for the South. Id.

149. Id.

150. Jonathan W. White, Abraham Lincoln and Treason in the Civil War, 53 (2011). The potential exceptions are the treason indictments for the free-state fighters during the Bleeding Kansas affair discussed above. Little record is made of these indictments - they do not appear, for example, in Hurst's generally comprehensive appendix of treason prosecutions prior to WWII.

151. See supra note 71.

152. Jonathan W. White. Abraham Lincoln and Treason in the Civil War, 10-11 (2011)

153. Id. at 10-12; RICHARD W. STEWART, supra note 148, at 205. 
through the state to the nation's capital. ${ }^{154}$ These actions briefly left Washington lightly defended as the Confederate army organized to move against the city. ${ }^{155}$

On April 27, 1861, Lincoln issued an order delegating to General Winfield Scott the authority to suspend the writ of habeas corpus. ${ }^{156}$ Federal troops quickly occupied Baltimore, training mortars on the city and arresting a prominent secessionist legislator. ${ }^{157}$ Their commanding officer speculated that, if the man "were hanged for treason," Maryland would fall in line. ${ }^{158}$ Baltimore's mayor and chief of police, both Confederate sympathizers, were apprehended and imprisoned in New York. ${ }^{159}$ Another man arrested was John Merryman, a lieutenant in the Maryland militia who had led one of the raids against bridges connecting the state to Pennsylvania. ${ }^{160}$ Merryman was charged with treason by military authorities. ${ }^{161}$ Army Headquarters in Washington issued an order to military authorities in Maryland: "you will hold in secure confinement all persons implicated in treasonable practices unless you should become satisfied that the arrest in any particular case was made without sufficient evidence of guilt."162

Merryman's habeas corpus petition, in which Chief Justice Taney found that only Congress may suspend the writ of habeas corpus, ${ }^{163}$ remains a seminal and controversial case. ${ }^{164}$ Parsing the uncertain aspects of that decision, including the jurisdiction of the court that issued it, ${ }^{165}$ Taney's motivations, ${ }^{166}$ and the actual effect of his order, ${ }^{167}$ is beyond the scope of this article. What is significant here is that Merryman was ultimately turned over to civil authorities and indicted by a federal grand jury for treason. ${ }^{168}$ Merryman joined about sixty other Marylanders indicted for treason for the riots. ${ }^{169}$

His indictment charged him with owing allegiance to the United States of

154. WhITE, supra note 152, at 14-23.

155. Id. at 17-19.

156. Seth Barrett Tillman, Ex Parte Merryman: Myth, History, and Scholarship, 224 MiL. L. REV. 481, 485 (2016).

157. WhITE, supra note 152 at 23.

158. Id. at 23 .

159. William Rehnquist, Civil Liberty and the Civil War: The Indianapolis Treason Trials, 72 IND. L.J. 927, 929 (1997).

160. White, supra note 152 at 14-23.

161. Ex parte Merryman, 17 F. Cas. 144, 147-48 (C.C.D. Md. 1861).

162. Tillman, supra note 156 at 552.

163. Ex parte Merryman, 17 F. Cas. at 152-53.

164. See Tillman, supra note 156.

165. See Tillman, supra note 156 at 504-05.

166. Taney, the author of the infamous Dred Scott decision, had sympathies that lay at least in part with the rebel cause. White, supra note 151 at 47-52.

167. Taney did not directly order Merryman's release. Instead, he wrote only, "I have exercised all the power which the constitution and laws confer upon me, but that power has been resisted by a force too strong for me to overcome.” Ex parte Merryman, 17 F. Cas. at 152.

168. White, supra note 152 at 46.

169. Id. 
America and acting to "compass, imagine and intend to raise and levy war, insurrection, and rebellion" against the United States. ${ }^{170}$ (The indictment's "compass and imagine" language was drawn from the English Treason Act of 1351, rather than the Treason Clause). Factually, it alleged that Merryman led armed men to destroy bridges and wires so as to "hinder, delay, and prevent the movement of military troops" as well as "prevent the speedy and rapid transmission of intelligence." 171 But despite the serious nature of these allegations, the case was never brought to trial. ${ }^{172}$ In 1867, after the war had ended, federal prosecutors entered a nolle prosequi in Merryman's interminable case. ${ }^{173} \mathrm{He}$ was subsequently elected to the state legislature, ${ }^{174}$ another demonstration of the fact that treason charges have often served to create public sympathy, rather than opprobrium, for the accused.

Why did federal prosecutors fail to obtain a conviction? The answer is difficult to reconstruct. Key judges, including Taney, had Confederate sympathies and did little to facilitate a speedy trial. ${ }^{175}$ Conviction by a Maryland jury was far from assured. ${ }^{176}$ After the war ended, an amnesty appeared likely, and even men whose disloyal conduct had been far more culpable than Merryman's were not charged with treason. ${ }^{177}$

Merryman's case exemplified a general pattern that emerged during the Civil War: Treason charges ultimately proved an ineffective and unfavored tool for enforcing loyalty to the Union, even during a time of open rebellion. Though a few treason charges were brought during the course of the war, ${ }^{178}$ Congress criminalized lesser offenses (which did not carry with them heightened constitutional protections) to deal with disloyalty, such as the crime of encouraging desertion. ${ }^{179}$ Congress also passed a statute explicitly allowing for reduced punishments in treason cases of lesser significance, ${ }^{180}$ but this did not lead to a wave of treason prosecutions.

While the war opened with large-scale treason arrests in Maryland, it closed with no treason prosecutions even for surviving Confederate generals like Robert E. Lee. ${ }^{181}$ Even Confederate President Jefferson Davis, initially indicted for treason, was not ultimately brought to trial. Various technical defects in his

170. The Indictment for Treason Against John Merryman, Baltimore Sun, July 1, 1861 (available in Readex, "America's Historical Newspapers").

171. Id.

172. WHITE, supra note 152 at $48-50$.

173. Tillman, supra note 156 at 493.

174. Id.at 494.

175. WhITE, supra note 152 at 47-52.

176. Id.

177. Id. at 60-61.

178. E.g. United States v. Greiner, 26 F. Cas. 36, 37 (E.D. Pa. 1861); United States v. Greathouse, 26 F. Cas. 18, 21 (N.D. Cal. 1863).

179. White, supra note 152 at 58.

180. Act of July 17, 1862, 12 Stat. $589 \S 1,2$.

181. White, supra note 152 at 58. 
indictment were noted by jurists at the time, ${ }^{182}$ and many doubted whether federal prosecutors could obtain a guilty verdict against Davis from a Virginia jury. ${ }^{183}$ Federal authorities also concluded that a treason prosecution would only increase Davis's popularity in the South. ${ }^{184}$ On the whole, leading Confederates escaped prosecution because the federal government opted for a lenient policy of amnesty. ${ }^{185}$

That said, the Civil War also saw the only death sentence for federal treason that has ever been carried out, rather than commuted or pardoned: the hanging of William Bruce Mumford. ${ }^{186}$ Incredibly, after decades of extreme reticence by courts regarding the use of the death penalty for federal treason, the action for which Mumford was executed was the mere removal of the United States flag from atop a federal building in New Orleans, after that city was taken by Union forces. ${ }^{187}$

Mumford was sentenced by a provisional court, presided over by a civilian lawyer but constituted by Lincoln under his executive authority. ${ }^{188} \mathrm{I}$ have located no surviving record of the trial to verify whether the procedural guarantees of the Treason Clause were observed. The Supreme Court later affirmed the judicial actions taken by the provisional court during the occupation of New Orleans, ${ }^{189}$ though it also subsequently stated that "not one execution on a federal treason conviction has taken place," 190 omitting Mumford's fate from history.

182. Case of Davis, 7 F. Cas. 63, 100 (C.C.D. Va. 1867) (considering the argument that "belligerent acts upon the rebel side performed in the due and orderly prosecution of a recognized civil war are not proper subjects of criminal prosecution during the conflict or after its close"). Chief Justice Chase also believed that Davis had been punished by Section Three of the Fourteenth Amendment, and that a further conviction would violate the principle of double jeopardy. Ian Mitchell, The Trial of Jefferson Davis and the Treason Controversy, 39 N. Ky. L. REv. 757, 758 (2012).

183. Francis MacDonnell, Reconstruction in the Wake of Vietnam: The Pardoning of Robert E. Lee and Jefferson Davis, 40 CIVIL WAR HISTORY 119, 122 n.5 (1994).

184. Id.

185. Lincoln's generous policy toward the South offered pardons to all who took a loyalty oath to the United States, with certain exceptions for high-ranking Confederates, who could petition for amnesty as individuals. See id. at 120. Andrew Johnson largely followed the same course after assuming the presidency, and he proclaimed a universal amnesty shortly before leaving office. Id. Congress made the questionable decision to posthumously restore full citizenship rights to Davis and Lee in the 1970s. See id. at 119.

186. Particulars of the Execution of William B. Mumford for Hauling Down the U.S. Flag, supra note 22; Carol Chomsky, The United States-Dakota War Trials: A Study in Military Injustice, 43 Stan. L. Rev. 13, n.319 (1990).

187. Particulars of the Execution of William B. Mumford for Hauling Down the U.S. Flag, supra note 22; Detlev F. Vagts, Military Commissions: The Forgotten Reconstruction Chapter, 23 AM. U. INT'L L. REv. 231, 240-41 (2008).

188. Vagts, supra note 187 at $240-41$.

189. See New Orleans v. Steamship Co., 87 U.S. 387, 393-94 (1874).

190. Cramer, 325 U.S. at 24. 
A new legal question arose after the end of the war, which demonstrates another unique aspect of treason as a crime: Could Union states charge their former Confederate citizens for state treason, even if they had been granted a federal pardon? The courts decided that they could not. ${ }^{191}$ As the Supreme Court of Appeals of West Virginia explained in 1866, although treason is "the highest crime known to the law . . . that is only true of treason against the State which enacted the law; for of treason against any other State the law takes no notice." 192 Adhering to the Confederacy had been treason against the sovereignty of the United States only, not against the sovereignty of individual states, and it thus could not be a state crime. ${ }^{193}$ Yet another paradox of treason: "though one of the highest crimes that can be committed against a State, [it] does not necessarily infer anything like the detestation which attends offences of much less guilt and danger." $" 194$

\section{E. Treason in the Era of Industrial Capitalism and Empire}

America's "Gilded Age" of the late Nineteenth Century was a time of yawning inequality and economic frustration. This frustration was abetted by a legal system that tended to override attempts at moderate political reform, such as when it held the first income tax to be unconstitutional in $1895 .{ }^{195}$ One result was the growth of the Populist Party, which upended the established political system by opposing the gold standard, ${ }^{196}$ advocating for nationalization of public utilities ${ }^{197}$ and challenging segregation and lynching in the post-Reconstruction South. ${ }^{198}$ Other left-wing populists gravitated toward the Socialist Party, led by

191. See Ex parte Quarrier, 2 W. Va. 569 (W.Va. 1866).

192. Id. at 571.

193. The decision thus aligns with Lynch, People v. Lynch, 11 Johns 549, 553 (N.Y. 1814), in holding that states may not charge treason against the United States.

194. Ex parte Quarrier, 2 W. Va. at 571 (quotation omitted).

195. Pollock v. Farmers' Loan \& Trust Co., 157 U.S. 429 (1895), modified on reh'g 158 U.S. 601 (1895).

196. See Williams Jennings Bryan, Address to the Democratic National Convention: The "Cross of Gold" (July 9, 1896).

197. See John D. Hicks, The Populist Revolt: AHistory of the Farmers' Alliance and THE PEOPLE's PARTY 442-43 (1931) (quoting platform demanding nationalization of the railroad, telephone, telegraph, and banking industries).

198. See C. Vann Woodward, Tom Watson: Agrarian Rebel 220 (1938) (quoting populist leader Tom Watson stating that blacks and whites "are kept apart that you may be separately fleeced of your earnings"); Gerald N. Magliocca, Constitutional False Positives and the Populist Moment, 81 Notre Dame L. Rev. 821, 862 n.234 (2006) (quoting populist platform condemning lynching). 
Eugene V. Debs. ${ }^{199}$ Debs, who greatly admired John Brown, ${ }^{200}$ advanced causes such as equal rights for women and an end to child labor alongside an end to "wage-slavery." 201 His performance as a socialist candidate for president demonstrated his rising influence: He won 6 percent of the national vote in $1912^{202}$ and received nearly a million votes as a write-in candidate in $1920 .^{203}$ Like his hero John Brown, Debs would ultimately pay a heavy price for his cause. ${ }^{204}$

Accompanying these left-wing political movements was a rise in labor activism, strikes, and demands for unionization. Many among the legal community came to see themselves as a bulwark against the Left. ${ }^{205}$ For example, in In re Debs, the Supreme Court upheld the use of injunctions followed by contempt charges, rather than jury trials, to break the Pullman Strike of $1885,{ }^{206}$ a trend decried by contemporary commentators as "government by injunction." 207 The Court reasoned that, if "a great body of [the inhabitants of a state], should combine to obstruct interstate commerce ... prosecutions for such offenses . . . would be doomed in advance to failure," and the "interests of the nation . . . would be at the absolute mercy of a portion of the inhabitants of that single state. ${ }^{208}$ In essence, the Court deemed a jury trial unwarranted because jurors would likely be sympathetic to the strikers.

Another significant case of this era was Presser v. Illinois, ${ }^{209}$ involving a

199. Eugene V. Debs, "Capitalism and Socialism" (Aug. 27, 1912) (criticizing the "Republican, Democratic and Progressive parties" for their economic stances), in LABOR AND Freedom: The Voice and Pen of Eugene V. Debs (“Labor and Freedom”) 173 (1916).

200. Eugene V. Debs, The Secret of Efficient Expression (1911) ("I studied the character of John Brown and he became my hero."), in LABOR AND FreEDOM at 19; Eugene V. Debs, Jesus, the Supreme Leader (1914) (citing Brown, alongside Christ, Lincoln, and Marx, as "palpitant and pervasive" historical figures), in LABOR AND FREEDOM at 23-24.

201. Eugene V. Debs, The Secret of Efficient Expression (1911) ("I believed that women should have all the rights men have, and I looked upon child labor as a crime."), in LABOR AND FREEDOM at 19; "The Fight for Freedom" (July 21, 1912) (advocating an end to "wage-slavery"), in LABOR AND FREEDOM at 162-63.

202. Neal Allen and Brian J. Brox, The Roots of Third Party Voting, 11 PARTy Politics 623, 626 (2005). A more fulsome account of the four-way election can be found in JAMES CHACE, 1912: Wilson, Roosevelt, TAFT AND Debs (2004).

203. See Sullivan v. Flannigan, 8 F.3d 591, 595 n.3 (7th Cir. 1993).

204. Infra notes 249-53.

205. See Gerald N. Magliocca, Why did the Incorporation of the Bill of Rights Fail in the Late Nineteenth Century?, 94 MinN. L. REv. 102, 129-31 (2009) (quoting Supreme Court Justice David Brewer's speech to the New York State Bar Association denouncing "the black flag of anarchism" and "the red flag of socialism").

206. Id. at 34-35.

207. See Charles Noble Gregory, Government by Injunction, 11 HARV. L. REV. 487 (1898).

208. In re Debs, 158 U.S. 564, 581-82 (1895).

209. Presser v. Illinois, 116 U.S. 252 (1886). 
Chicago labor group that also conducted militia drills. ${ }^{210}$ The defendant was charged with violating an Illinois law prohibiting any group other than the state militia from "drill[ing] or parad[ing] with arms in any city or town of this state, without the license of the governor[.]"211 The Supreme Court rejected First and Second Amendment challenges, holding that state governments, "unless restrained by their own constitutions," have the power to prohibit assemblies and regulate military associations. ${ }^{212}$ "To deny [this] power would be to deny the right of the state to disperse assemblages organized for sedition and treason," the Court reasoned. ${ }^{213}$ This wide deference to the states, hostility toward organized labor, and hyperbolic invocation of treason set the stage for a series of labor-related state treason cases.

In 1892, steelworkers at a Pittsburgh plant owned by Andrew Carnegie engaged in a lockout known as the Homestead Strike. In response, the Chief Justice of the Pennsylvania Supreme Court arranged to have thirty-three union workers indicted for treason against the state of Pennsylvania, an unprecedented expansion of the law of treason. ${ }^{214}$ In his charge to the grand jury, Chief Justice Paxson instructed that "when a large number of men arm and organized themselves by divisions and companies, appoint officers, and engage in a common purpose to defy the law, to resist its officers, and to deprive any portion of their fellow-citizens of the rights to which they are entitled . . . it is a levying of war against the state, and the offence is treason." ${ }^{215}$ Taken to an extreme, and combined with Lochner-era doctrines concerning freedom of contract, Paxson's interpretation of the law threatened to make unionization treasonous.

Paxson belittled the strikers' grievances before the grand jury: "We can have some sympathy with a mob driven to desperation by hunger, as in the days of the French revolution, but we can have none for men receiving steady employment, at exceptionally high wages, in resisting the law[.]" ${ }^{\prime 216}$ He characterized public sympathy for the striking workers as a "diseased state of public opinion growing up with regard to disturbances of this nature." ${ }^{17}$ But his use of treason charges was a bridge too far: his actions caused an uproar and drew condemnation from other lawyers, including a former justice of the Pennsylvania Supreme Court, who published a critique that there could be no treason "without a purpose against the state. ${ }^{, 18}$ In the face of protest, the Homestead treason charges were ultimately

210. Magliocca, supra note 205, at 125-26.

211. Presser, 116 U.S. at 253. The law was similar to the one violated by Joseph Smith at Nauvoo.

212. Id. at 267.

213. Id. at 268.

214. Hurst, supra note 14, at 199; Arthur G. Burgoyne, Homestead: A Complete History of the Struggle of July, 1892 Between the Carnegie Steel Company, Limited, and the Amalgamated Association of Iron And Steel Workers 197-99 (1893).

215. The Homestead Case, 1892 WL 3637, at **6 (Pa. O. \& T. Oct. 1892).

216. Id. at **3.

217. Id. at $* * 4$.

218. BuRGOYNE, supra note 214, at 202. 
dropped. $^{219}$

Paxson's words and actions reveal him to have been an anti-labor ideologue, misusing the treason charge in precisely the politically motivated manner that the framers had feared. Yet even Willard Hurst, the preeminent scholar of American treason law, appeared to believe as late as 1945 that the charge was applicable to labor actions. ${ }^{220}$ And Homestead would not be the last time state treason charges were used against labor activists.

After the Battle of Blair Mountain, a massive labor action by West Virginian coal miners attempting to unionize that ended in violence, ${ }^{221}$ William Blizzard and Walter Allen of the United Mine Workers of America were charged with treason against the state of West Virginia. ${ }^{222}$ In a striking coincidence, they were brought to trial in the same courthouse in which John Brown and his supporters had been tried. ${ }^{223}$ Blizzard was acquitted, but Allen was convicted. ${ }^{224}$ He remains the last man convicted of state treason.

A separate expansion of treason prosecutions arose during America's colonial occupation of the Philippines, where several Philippine rebels were charged with treason against the United States. ${ }^{225}$ Philippine law established that "[e]very person, resident in the Philippine Islands, owing allegiance to United States, or the Government of the Philippine Islands, who levies war against them or adheres to their enemies, giving them aid and comfort . . . is guilty of treason. . ."226 Under this law, residents of the Philippines "owed allegiance to the United States Government in the Philippine Islands." ${ }^{227}$ In three cases in which Philippine insurgents were charged with treason against the United States, two were acquitted for want of two witnesses to an overt act, while one was convicted. ${ }^{228}$

219. HuRST, supra note 14, at 200.

220. See Willard Hurst, Treason in the United States, 58 HARV. L. REV. 806, 822-23 (1945) (noting a lack of prosecutions for "the railroad strikes of 1877, the Haymarket affair of 1886 . . and the Pullman strike in 1894").

221. Brandon Nida, Demystifying the Hidden Hand: Capital and the State at Blair Mountain, 47 Hist. ARCH. 52, 63 (2013).

222. Bituminous Operators Special Committee of the United State Coal Commission, The United Mine Workers in West Virginia, HathiTRust at 66 (May 3, 1924) (herein "Mine Workers in West Virginia") https://babel.hathitrust.org/cgi/pt?id=njp.32101058847151\&view=1up\&seq=1 [https://perma.cc/MWR7-7FW3]

223. John McVey, Historic Jefferson County Courthouse in Charles Town Site of Two Treason Trials, W. VA. LAWYER, Sept. 2013, at 32.

224. Mine Workers in West Virginia, supra note 222, at 66.

225. HURST, supra note 14, at 262-63.

226. United States v. Lagnason, 3 Phil. Rep. 472, 477 (S.C. 1904).

227. Id. at 494 .

228. Id . at 482-83. The fact that the American government generally considered Confederate rebels to be valid belligerents while later considering Philippine rebels to be traitors against the United States boggles the mind. Compare HuRst, supra note 14, at 262 ("Strong arguments were made [in the case of Jefferson Davis] that treason charges could not properly be brought against those conducting a rebel government which had achieved the status of a recognized belligerent ...”) with 
Thus, the heightened evidentiary standard frustrated treason prosecutions even during colonial occupation.

These decisions appear to have contemplated attacks on the Philippine provincial authorities as treason against the government of the Philippine Islands, whereas attacks on U.S. forces would be treason against the United States, treating the United States and the occupied Philippine Islands as distinct entities. ${ }^{229}$ Thus, even in America's imperial project in the Philippines, the United States reconstructed its unique system of dual sovereigns demanding dual allegiances, producing two potential bodies of treason law. Though the rebels were charged with treason against the United States, their cases were decided by the Philippine Supreme Court rather than a U.S. federal court. The decisions thus straddle the line between federal and state treason law.

Longstanding precedent held that a state court could not hear a charge of treason against the United States. ${ }^{230}$ The Supreme Court would confirm this principle in 1920, writing that "states may not punish treason against the United States . . . although indirectly acts of treason may affect them vitally." ${ }^{231}$ Territories, on the other hand, could hear charges of treason against the United States, but not against the territorial government. And yet the Philippine Supreme Court uniquely had jurisdiction over both treason against the Philippine Islands and treason against the United States. The contradiction highlights the messy way in which colonialism fit within the U.S. legal system.

\section{F. World Wars, Cold War, and Modern Treason Law}

Treason allegations, labor struggle and war intersected again in early Twentieth Century Oklahoma. Tenant farmers there were immersed in poverty. They were forced to rely on loans with 20 to 200 percent interest, and in some cases, even 2,000 percent interest, as they labored to grow cotton on poor soil, working twice the man-hours per acre as farmers in Mississippi or Louisiana. ${ }^{232}$ In Oklahoma counties with high rates of tenancy, Debs received over 30 percent of the vote in the 1914 presidential election. ${ }^{233}$ Some farmers moved further left than Debs' Socialist Party, particularly after cotton prices collapsed, joining a secret organization called the Working Class Union or WCU. ${ }^{234}$ Unlike the

$i d$. at 262-63 ("armed effort to overthrow the [colonial Philippine] government held to be a levying of war").

229. Lagnason, 3 Phil. Rep. at 487-88 (describing defendant's rebel band as having "frequently attacked the provincial government, and on the 29th and 30th of October, 1902, made an attack against the United States government, as constituted in the said pueblo of Murcia.")

230. Lynch, supra note 53, at 552; Quarrier, supra note 133 at 571-72. See also McConkie, supra note 6, at 294.

231. Gilbert v. Minnesota, 254 U.S. 325, 342 (1920) (internal citations omitted).

232. Nigel Anthony Sellars, Treasonous Tenant Farmers and Seditious Sharecroppers: The 1917 Green Corn Rebellion Trials, 27 OKLA. CiTy U. L. ReV. 1097, 1112-13 (2002).

233. Id. at 1114 .

234. Id. at $1117-18$. 
Socialist Party or the IWW, the WCU did not officially reject violence as a means to political change. ${ }^{235}$

These tenant farmers felt betrayed by Woodrow Wilson's entry into World War I in 1917, as many had voted for his reelection on the ground that he had kept the U.S. out of the war since $1914 .^{236}$ The draft boards set up to administer conscription for the war were discriminatory, tending to grant exemptions to middle class whites at the expense of farmers, laborers, African Americans, and Native Americans. ${ }^{237}$ This volatile mix of discontent led the WCU to organize an abortive uprising, known as the Green Corn Rebellion. ${ }^{238}$

A group of WCU rebels assembled at an Oklahoma farm in Seminole County under a red socialist flag and began burning railroad trestles and cutting telegraph wires. But they were soon met by law enforcement posses armed by the National Guard, and they were dispersed shortly after they assembled. A few men were killed (all by the posses), and some sheriffs and deputies were wounded. A broad crackdown ensued against WCU members: 458 men were arrested, and 192 were indicted.

The U.S. Attorney for the Eastern District of Oklahoma announced that he would try the men for treason and seek the death penalty. ${ }^{239}$ He would have faced a difficult task: Indictments against those WCU members who did not join the armed assembly would have failed for the same reason why Burr was acquitted. But the Department of Justice intervened, shifting the prosecution from treason to the newly enacted Espionage Act, which allowed for easier convictions. ${ }^{240}$

The Espionage Act was passed after Wilson had lobbied Congress "for legislation to suppress disloyal activities." ${ }^{241}$ Section Three of the Espionage Act made it a crime to "obstruct the recruit[ment] or enlistment" of the military, which would ultimately be conflated with criticism of the war. Another section made it a crime to conspire to violate Section Three, if any member of the conspiracy then went on to actually violate Section Three. The act also allowed the Postmaster General to exclude from the mail service any publication that violated the act or "advocate[ed] or urg[ed] treason, insurrection or forcible resistance to any law of the United States." During Congressional discussion of the provision, one representative explained that the Socialist Party would have the right to affirm its allegiance to internationalism, but that it would be "treasonable" for the party to argue that the war could not be justified - a vast overreading of actual treason law. ${ }^{242}$ Several states followed suit, banning "criminal

235. Id. at 1118. That said, many members sought reforms legally, and the group organized and funded lawsuits against local banks for violating usury laws. $I d$. at 1119 .

236. Id. at 1121-22.

237. Id. at 1124 .

238. Id. at 1128 .

239. Id. at 1129.

240. Id.

241. Geoffrey R. Stone, Judge Learned Hand and the Espionage Act of 1917: A Mystery Unraveled, 70 CHI. L. REV. 335, 336 (2003).

242. Id. at 350 . 
syndicalism." ${ }^{243}$ These laws were ostensibly aimed against organizations that advocated violence for political goals, but in practice they were used against nonviolent organizations such as the IWW. ${ }^{244}$ Oklahoma went so far as to ban the flying of red flags. ${ }^{245}$

The Espionage Act was used to convict participants in the Green Corn Rebellion, leading to sentences of up to ten years. ${ }^{246}$ This was merely the beginning of the act's deployment against ostensibly disloyalty. All told, 2,168 individuals were prosecuted under the act, resulting in 1,055 federal convictions. ${ }^{247}$ The vast majority of these prosecutions were brought under Section Three, rather than those sections targeting traditional spying. ${ }^{248}$

Overreach abounded. Eugene Debs, who (like Wilson) had opposed America's entry to the war during the 1914 presidential election, was jailed for giving an antiwar speech "so expressed that its natural and intended effect would be to obstruct recruiting." 249 His conviction was affirmed by the Supreme Court, ${ }^{250}$ in an opinion now considered to be wrongly decided. ${ }^{251}$ From prison, he received nearly a million write-in votes for president. ${ }^{252}$ Though he was not (and could not have been) convicted of treason, Wilson subsequently described Debs as "a traitor to his country." 253

Rose Pastor Stokes, also active in the Socialist Party, was likewise sentenced after making antiwar comments deemed to discourage participation in the draft. ${ }^{254}$ She had been addressing the Women's Dining Club of Kansas City, which included no men - she thus could not possibly have intended to obstruct military recruitment. $^{255}$

Several ministers were prosecuted for preaching pacifist religious doctrines, demonstrating that free-exercise rights were not respected any more than free-

243. See, e.g. Berg v. State, 233 P. 497, 499 (Okla. Ct. Crim. App. 1925) (prosecution of IWW member for criminal syndicalism, rejecting contention that the law was "an attempt to create and define a new kind of treason").

244. Sellars, supra note 232, at 1139-40.

245. Id. at 1140 .

246. Id. at 1138 .

247. Id. at 1139 .

248. Stone, supra note 241 , at 337 n.13.

249. Debs v. United States, 249 U.S. 211,215 (1919).

250. Id. at 217.

251. Sullivan v. Flannigan, 8 F.3d 591, 595 n. 3 (7th Cir. 1993) ("Debs was in prison for expressing political views ... that are now protected by the First Amendment.”)

252. Id.

253. See Burl Noggle, Into the Twenties: The United States from Armistice to NORMALCY, 113 (1974).

254. 13 John Davidson lawson, American State Trials: A Collection of the Important and Interesting Criminal Trials which Have Taken Place in the United States, from the Beginning of Our Government to the Present Day, 790-91, (1921).

255. Stone, supra note 241, at 339. 
speech rights were. ${ }^{256}$ In 1918, the New York Times quoted DOJ officials as stating that "[d]isloyalty fostered by certain religious sects has been growing in the United States ... Several German and Austrian preachers and Sunday school teachers have been indicted for disloyal utterances, and many others . . . have been warned to desist from criticizing the nation's war motives."257

On occasion, Espionage Act prosecutions could result in farce as well as tragedy. The Southern District of California ordered the seizure of all copies of a film about the American Revolution, titled "The Spirit of '76," because it portrayed British soldiers in a negative light. The court held that the film "may have the tendency ... of creating animosity or want of confidence between us and our allies." 258

This mass repression of political dissent would have been unthinkable under the Treason Clause, with its constitutional evidentiary limitation, its prohibition on judicial or legislative expansion, and the traditional disapproval with which courts, political leaders, and voters have treated expansive treason prosecutions. Indeed, the 2,168 Espionage Act prosecutions would have exceeded by an order of magnitude the total number of state and federal treason prosecutions ever conducted in American history. Ironically, those Americans who actually served as agents of Imperial Germany were properly indicted for federal treason, suggesting that the Espionage Act may have been unnecessary to prevent actual wartime espionage. ${ }^{259}$ In 1919, the Supreme Court considered whether Espionage Act prosecutions should have been properly brought under the Treason Clause or not at all, but it rejected the argument without analysis. ${ }^{260}$

Tom Bell has argued that World War II's treason cases dangerously expanded treason law, creating a law of "treasonous expression" that infringed on First Amendment-protected dissent. ${ }^{261}$ But in comparison to the wild abandon with which political dissent was suppressed during the first war, the second war's treason cases appear restrained. True, seven Americans who produced anti-U.S. propaganda on behalf of Axis governments were prosecuted. ${ }^{262}$ But prewar

256. Id ; 12 John Davidson Lawson, American State Trials: A Collection of the Important and Interesting Criminal Trials which Have Taken Place in the United States, from the Beginning of Our Government to the Present Day, 897-99, (1921).

257. Warn Seditious Pastors, N.Y. Times, Mar. 31, 1918, at 16.

258. United States v. Motion Picture Film "The Spirit of '76," 252 F. 946, 948 (S.D. Cal. 1917).

259. See, United States v. Werner, 247 F. 708 (E.D. Pa. 1918), aff'd 251 U.S. 466 (1919); United States v. Fricke, 259 F. 673, 681 (S.D.N.Y. 1919); United States v. Robinson, 259 F. 685 (S.D.N.Y. 1919).

260. Frohwek v. United States, 249 U.S. 204, 210 (1919) ("Some reference was made in the proceedings and in argument to the provision in the Constitution concerning treason, and it was suggested on the one hand that some of the matters dealt with in the Act of 1917 were treasonable and punishable as treason or not at all, and on the other that the acts complained of not being treason could not be punished. These suggestions seem to us to need no more than to be stated.")

261. Bell, supra note 18, at 1002-04.

262. Id. at 1003 . 
precedent that treason could not be based on words alone ${ }^{263}$ was neither reversed nor ignored. It was only those Americans who joined the war efforts of enemy nations - not those who joined in domestic political dissent - who faced treason charges for conduct during World War II.

The key case arising from the second war was United States v. Cramer, ${ }^{264}$ the first treason case to reach the Supreme Court in over a century, involving an American who assisted a former roommate who had joined the Nazi armed forces and returned via a submarine to sabotage the American war industry. ${ }^{265}$ The Court reversed Cramer's conviction because the overt act for which there were two witnesses, a meeting between the two in a bar, was innocent on its face and did not manifest treasonous intent. ${ }^{266}$ Two death sentences resulted from other WWII treason cases, but both were subsequently commuted. ${ }^{267}$ Thus, two general characteristics of treason prosecutions - heightened evidentiary standards and a likelihood of an eventual commutation-were respected even during America's participation in the bloodiest war ever fought.

Treason prosecutions played virtually no role during the Cold War. A partial explanation is the fact that war was never declared against any communist nations, and at least some authority can be read to suggest that war must be formally declared for a nation to constitute an "enemy" to which a traitor may adhere. ${ }^{268}$ Another potential explanation is that the Cramer decision raised the difficulty of obtaining a conviction by adopting a restrictive view of the constitutional evidentiary standard, dissuading prosecutors for trying. ${ }^{269}$ But equally important is the fact that, during the era of the "Red Scare," courts allowed prosecutors to obtain the steepest punishments for lesser charges, rendering the procedural protections of the Treason Clause largely irrelevant.

The paradigmatic examples of this prosecutorial tilt are Julius and Ethyl Rosenberg, both executed for the lesser crime of espionage for passing secrets to the Soviet Union. At trial, the prosecution compared the Rosenbergs to Benedict Arnold and referred to their conduct as "treasonable." 270 Julius appealed his death sentence to the Second Circuit, partially on the ground that he had not been charged with treason and afforded the protections of the Treason Clause. ${ }^{271} \mathrm{In}$ Cramer, the Supreme Court had noted that it would not "intimate that Congress

263. See Berg, 233 P. at 500 (criminal syndicalism prosecution, noting that treason requires "more than mere words to constitute the offense").

264. 325 U.S. 1 (1945).

265. For another perspective on the Cranmer decision, see Crane, supra note 18.

266. 325 U.S. 1.

267. Eisenhower Spares Life of U.S. Traitor, N.Y. TimES, Nov. 3, 1953.

268. See Fricke, 259 F. at 681; United States v. McWilliams, 54 F. Supp. 791, 793 (D.D.C. 1944) ("The averments as to what happened between 1933 and 1940 cannot be deemed a charge of conspiracy to commit treason since an essential element therein is aid and comfort to 'enemies' and Germany did not become a statutory enemy until December 1941.”)

269. See generally Crane, supra note 18.

270. Holzer, supra note 18 , at 182 n.8.

271. United States v. Rosenberg, 195 F.2d 583 (2d Cir. 1952). 
could dispense with the two-witness rule merely by giving the same offense another name." 272 Thus, the Court had gestured toward a potential doctrine requiring a full treason prosecution for disloyalty offenses against American citizens, particularly if maximum punishment was being pursued. However, Rosenberg was granted no relief. ${ }^{273}$ While the United States has executed only one American for treason, it executed two members of the Rosenberg family for a lesser offense, raising questions about whether the Treason Clause and its protections are now superfluous. Similarly, in a post-Cold War case arising out of the first World Trade Center bombing, the Second Circuit determined that the federal sentencing guidelines for treason could be applied in a conviction for seditious conspiracy. ${ }^{274}$

While treason jurisprudence appeared to vanish during the Cold War, it saw at least a partial revival after 9/11. Many commentators argued for an increased use of the charge in the War on Terror, particularly after the capture of Talibanvolunteer John Walker Lindh. ${ }^{275}$ The first treason indictment since the Second World War was issued in 2006 against Adam Gadahn, an American citizen who joined al-Qaeda and created propaganda videos with Osama bin-Laden. ${ }^{276}$ Gadahn was never brought to trial; he was killed by a drone strike in $2015 .{ }^{277}$

\section{INCORPORATION OF THE TREASON CLAUSE}

In this section, I will argue that the Treason Clause should be incorporated against the states by the Fourteenth Amendment, limiting state treason prosecutions. Before doing so, I will address two threshold questions: whether treason remains chargeable at the state level (if not, incorporation would serve no purpose), and whether the offense of treason remains relevant enough for questions of incorporation to be worth considering.

\section{A. State Treason in Contemporary America}

Some authors, including Larson, have implied that the contemporary viability of state treason laws remains an open question. ${ }^{278}$ McConkie has contended that they remain valid, ${ }^{279}$ and I conclude that he is correct. The fact that the question can be considered open at all likely results from the fact that many state prosecutions have been overlooked: even McConkie, whose analysis of state

272. Cramer, 325 U.S. at 45.

273. Rosenberg, 195 F.2d at 583.

274. United States v. Rahman, 189 F.3d 88 at 111-14 (2d Cir. 1999).

275. E.g., Holzer, supra note 18.

276. Crane, supra note 18, at 636.

277. Statement by the Press Secretary, White House President Barack Obama (Apr. 23, 2015), https://obamawhitehouse.archives.gov/the-press-office/2015/04/23/statement-press-secretary [https://perma.cc/5QF5-G87Q].

278. See Larson, supra note 15, at 886 ("Whether treason against an individual state was or is a viable crime is a fascinating question ...”).

279. McConkie, supra note 19, at 335. 
treason law is thorough, nonetheless wrote that "[s]ince ratification of the Constitution, state courts have completed only two treason prosecutions," identifying Brown and Dorr. ${ }^{280}$

State treason prosecutions have been undertaken by at least eight states and treason convictions have been obtained by three states, resulting in four executions. No constitutional development has occurred since the conviction of Walter Allen by West Virginia that would render state charges invalid. Of course, it is true that no state treason prosecution has been attempted since the 1920s. But the federal charge remained dormant between the Second World War and 2006, just as it had remained largely dormant between Burr's conspiracy and the Civil War. Lack of prosecution over a period of time does not render a charge invalid.

Today, the majority of state constitutions include treason clauses that mirror that of the U.S. Constitution. These are Alabama, ${ }^{281}$ Alaska, ${ }^{282}$ Arizona, ${ }^{283}$ Arkansas ${ }^{284}$ California, ${ }^{285}$ Colorado, ${ }^{286}$ Connecticut, ${ }^{287}$ Delaware, ${ }^{288}$ Florida, ${ }^{289}$ Georgia, ${ }^{290}$ Idaho, ${ }^{291}$ Indiana, ${ }^{292}$ Iowa ${ }^{293}$ Kansas, ${ }^{294}$ Kentucky, ${ }^{295}$ Maine, ${ }^{296}$ Michigan, ${ }^{297}$ Minnesota, ${ }^{298}$ Mississippi,${ }^{299}$ Missouri, ${ }^{300}$ Montana, ${ }^{301}$ Nebraska,${ }^{302}$

280. Id. at 300 (omitting Virginia's convictions of Coppock, Hazlet, and Stevens, Virginia's acquittals of Green and Copeland, West Virginia's conviction of Blizzard, and West Virginia's acquittal of Allen).

281. Ala. Const. art. I, $\S 18$.

282. Alaska Const. art. I, $\S 10$.

283. ARIZ. CONST. art. II, $\S 28$.

284. ARK. CONST. art. $2, \S 14$.

285. CAL. Const. art. I, $\S 18$.

286. Colo. Const. art. II, $\S 9$.

287. Conn. Const. art. IX, $\S 4$.

288. Del. Const. art. VI, $\S 3$.

289. Fla. CONST. art. I, $\S 20$.

290. GA. Const. art. I, § I, para. XIX. The Georgia Constitution uses the term "insurrection" in place of "levying war."

291. IDAHO CONST. art. V, $\S 5$.

292. IND. CONST. art. $1, \S \S 28-29$.

293. IowA Const. art. I, $\S 16$.

294. Kan. Const. B. of R. § 13.

295. Ky. CONSt. § 229.

296. ME. Const. art. I, $\S 12$.

297. Мich. Const. art. I, $\S 22$.

298. Minn. Const. art. I, $\S 9$.

299. Miss. Const. art. 3, $\S 10$.

300. Mo. Const. art. I, $\S 30$.

301. Mont. Const. art. II $\S 30$.

302. NeB. CONST. art. I, $\S 14$. 
Nevada,${ }^{303}$ New Jersey, ${ }^{304}$ New Mexico, ${ }^{305}$ North Carolina, ${ }^{306}$ North Dakota, ${ }^{307}$ Oklahoma, ${ }^{308}$ Oregon, ${ }^{309}$ South Carolina, ${ }^{310}$ South Dakota, ${ }^{311}$ Texas, ${ }^{312}$ Utah, ${ }^{313}$ Washington, ${ }^{314}$ West Virginia, ${ }^{315}$ Wisconsin, ${ }^{316}$ and Wyoming. ${ }^{317}$ In each of these states, the legislature is prohibited from defining treason as anything other than levying war against the state or adhering to its enemies, giving them aid and comfort. Furthermore, defendants accused of treason may only be convicted upon testimony of two witnesses to the same overt act, or upon confession in open court.

The constitutions of Massachusetts, Maryland, Pennsylvania, and Vermont prohibit treason convictions by bills of attainder but do not provide the full protections embodied in the Treason Clause. ${ }^{318}$ The constitutions of Illinois, ${ }^{319}$ Ohio, ${ }^{320}$ Tennessee, ${ }^{321}$ Virginia, $^{322}$ and New York $^{323}$ contemplate treason

303. NeV. Const. art. $1, \S 19$.

304. N.J. CONST. art. I, para. 17.

305. N.M. CONST. art. II, § 16.

306. N.C. Const. art. I, $\S 29$.

307. N.D. Const. art. I, $\S 17$.

308. OKLa. Const. art. II, $\S 16$.

309. OR. CONST. art. I, $\S 24$.

310. S.C. CONST. art. I, $\S 17$.

311. S.D. CONST. art. VI, $\S 25$.

312. TEX. CONST. art. I, $\S 22$.

313. UTAH CONST. art. I, $\S 19$.

314. WASH. CONST. art. I, $\S 27$.

315. W. VA. Const. art. II, $\S 6$.

316. Wis. CONST. art. I, $\S 10$.

317. Wyo. Const. art. 1, § 26.

318. Mass. Const. Pt. 1, art. XXV ("No subject ought, in any case, or in any time, to be declared guilty of treason or felony by the legislature."); MD. DEC. OF R. art. 18 ("That no Law to attaint particular persons of treason or felony, ought to be made in any case, or at any time, hereafter."); PA. CONST. art. I, $\S 18$ ("No person shall be attainted of treason or felony by the Legislature."); VT. CONST. $§ 60$ ("No person ought in any case, or in any time, to be declared guilty of treason or felony, by the Legislature ...").

319. ILl. Const. art. IV, $\S 12$.

320. Он. CONST. art. III, $\S 11$ ("Upon conviction for treason, the Governor may suspend the execution of the sentence, and report the case to the General Assembly, at its next meeting, when the General Assembly shall either pardon, commute the sentence, direct its execution, or grant a further reprieve.")

321. Tenn. Const. art. II, $\S 13$. Like the Treason Clause of the U.S. Constitution, the Tennessee Constitution does prohibit the punishment of corruption of blood. Art. I, $\S 12$. However, this does not apply specifically to treason, and that constitution does not require two witnesses to the same overt act or limit the scope of treason charges.

322. VA. Const. art. IV, $\S 9$ (immunity for members of the General Assembly in all cases other than treason, felony, or breach of the peace).

323. NY. CONST. art IV, $\S 4$ (limiting the governor's power to pardon in cases of treason). 
prosecutions but do not provide any protections to those accused of the crime, as do the constitution of Puerto Rico ${ }^{324}$ and the Organic Act of the U.S. Virgin Islands. ${ }^{325}$ The constitutions of Hawaii, Louisiana, New Hampshire, and Rhode Island are silent as to treason. ${ }^{326}$

Of the minority of states that do not provide full constitutional protections to those accused of treason, several have enacted criminal statutes that go no further than the Treason Clause. Rhode Island, for example, criminalizes treason to the same extent as the Treason Clause, defining it as "levying war against this state" or "adhering to the enemies of this state, giving them aid and comfort," with a punishment of life in prison (the sentence that state handed down to Dorr). ${ }^{327}$ The Louisiana Code defines the crime similarly, but provides that it is punishable by death. ${ }^{328}$ Notably, the Louisiana Code purports to apply both to treason against Louisiana and against the United States. ${ }^{329}$ To the extent the statute purports to make treason against the United States punishable by state law, it is unconstitutional. $^{330}$

Two states define treason so as to extend the charge beyond the scope of the federal version. Vermont's definition of treason includes treasonous conspiracy, ${ }^{331}$ contrary to how the Supreme Court interpreted the Treason Clause in the Burr Conspiracy cases. And as it did during the trial of John Brown, Virginia state law continues to define five categories of treason, rather than the two defined under federal law:

(1) Levying war against the Commonwealth; (2) Adhering to its enemies, giving them aid and comfort; (3) Establishing, without authority of the Legislature, any government within its limits separate from the existing

324. L.P.R.A. Const. art. III, $\S 14$ (Privileges and immunities for the Legislative Assembly do not extend to treason, felony, or breach of the peace).

325. V.I.C. Rev. Org. Act of $1954 \S 6$.

326. The crime of treason is referenced in the New Hampshire Constitution, which provides that "[n]o person shall have the right to vote under the constitution of this state who has been convicted of treason, bribery or any willful violation of the election laws of this state or of the United States . ..” N.H. ConST. Pt. I, art. 11. However, as this clause could be read to refer only to convictions for treason under federal law, I have grouped New Hampshire alongside the states whose constitutions do not explicitly reference state treason charges.

327. R.I. GEN. LAWS § 11-43-1.

328. LA. R.S. § 14:113.

329. Id. ("Treason is the levying of war against the United States or the state of Louisiana, adhering to enemies of the United States or of the state of Louisiana, or giving such enemies aid and comfort.").

330. Gilbert v. Minnesota, 254 U.S. 325, 342 (1920) ("The states may not punish treason against the United States, although indirectly acts of treason may affect them vitally.").

331. 13 V.S.A. $\S 3401$ ("A person owing allegiance to this State, who levies war or conspires to levy war against the same, or adheres to the enemies thereof, giving them aid and comfort . . . shall be guilty of treason against this State and shall suffer the punishment of death.") (emphasis added). 
government; (4) Holding or executing, in such usurped government, any office, or professing allegiance or fidelity to it; or (5) Resisting the execution of the laws under color of its authority. ${ }^{332}$

The constitutionality of these definitions is discussed below in Section C.

\section{B. The Contemporary Relevance of Treason}

Regardless of its theoretical viability at the state and federal level, has the offense of treason become anachronistic? The question is more complex than it appears at first glance. On the one hand, federal treason appears to have some renewed relevance in the post-9/11 era. Carlton Larson has forcefully argued that treason is the appropriate charge for terrorist attacks, both on the ground that terrorists levy war against the United States and that organizations like al-Qaeda are "Enemies" within the bounds of the Treason Clause. ${ }^{333}$ As he pointed out, if the 9/11 attacks "did not constitute levying war against the United States, it is hard to imagine what would." ${ }^{334}$ At least one treason indictment has been issued during the War on Terror.

And even if one does not conclude that the charge is appropriate for foreign terrorist organizations, whose members may not tend to owe allegiance to the United States, it would appear apt for domestic terrorists like Timothy McVeigh. ${ }^{335}$ Such terrorists may strike at either federal or state facilities, and their actions could thus constitute either federal or state treason. Likewise, in recent years several extremist militias have resisted federal and state authority through armed standoffs with government agents, ${ }^{336}$ and a similar group was recently charged with conspiring to kidnap a sitting state governor. ${ }^{337}$ These types of

332. VA. Code AnN. $§ 18.2-481$. Virginia's definition of treason as encompassing the professing of allegiance to a usurped government cuts against both the Treason Clause and the traditional common law of treason, which required allegiance even to usurpers in de facto control of territory. See In re Sherretz, 40 Haw. 366, 380 (Haw. 1953) (At common law, "it was held that while a usurper of the crown was in full possession of the sovereignty any attempts against the usurper are treason unless in defense or aid of the rightful king, as allegiance is due to the de facto king. Upon this doctrine, after Edward IV recovered the crown which had long been detained by the House of Lancaster, treasons committed against Henry VI were capitally punished though Henry had been declared a usurper by parliament.") (emphasis added). See also Thorington v. Smith 75 U.S. 1, 9-10 (1869).

333. Larson, supra note 15 , at $914-5$.

334. Id. at $912-25$.

335. Id. at 913 .

336. See Anne Bonds \& Joshua Inwood, Beyond White Privilege: Geographies of White Supremacy and Settler Colonialism. Progress in Human Geography 1, 9-11 (2015) (standoff with government authorities in Nevada); Joshua Inwood and Anne Bonds, Property and Whiteness: the Oregon Standoff and the Contradictions of the U.S. Settler State, SpaCE AND POLITY 1, 1-5 (2017) (same, in Oregon).

337. See Complaint, United States v. Fox, No. 1:20-mj-0416, ECF No. 1 (W.D. Mich. Oct. 6, 2020). 
actions might give rise to federal or state treason charges in the future.

Nor do I agree with George Fletcher's argument that American society has become "ambivalent about treason" because it "no longer conforms to our shared assumptions about the liberal nature and purpose of criminal law." ${ }^{338}$ Demands to hold public figures criminally accountable for disloyalty have waxed and waned throughout history, but they do not appear to be waning today: President Trump-himself accused of treason by critics for various alleged connections with Russia ${ }^{339}$ - declared during the writing of this article that a whistleblower was "close to a spy," asking rhetorically, "You know what we used to do in the old days . . . with spies and treason, right? We used to handle them a little differently than we do now." 340

But there is good reason to question why many modern prosecutors would bother seeking an indictment for treason. Two features of treason convictions once distinguished the crime from other offenses: harsher punishments and social opprobrium, but these no longer apply in modern cases.

In previous eras, treason allowed a prosecutor to obtain a heightened punishment. Under English law prior to the Revolution, treason convictions brought with them extreme, medieval forms of punishment that differentiated the charge: disembowelment, drawing and quartering, burning at the stake, corruption of the blood. ${ }^{341}$ For most of American history, treason carried with it a possible death sentence. But, as in the case of the Rosenbergs, modern prosecutors have obtained death sentences for lesser crimes not accompanied by the strict constitutional requirements of treason. And today, it is an open question whether the death sentence for treason would even comport with the Eighth Amendment's prohibition on cruel and unusual punishment. ${ }^{342}$ In a non-capital case, the Second Circuit has approved the use of the treason sentencing guidelines for the crime of seditious conspiracy, implying that a treason charge will not necessarily result in a harsher sentence than a seditious conspiracy charge. ${ }^{343}$ Thus, treason is no longer differentiated by harsher punishment.

338. Fletcher, supra note 17, at 1612.

339. E.g. Charles Blow, Trump: Treasonous Traitor, N.Y. Times (July 15, 2018) https://www.nytimes.com/2018/07/15/opinion/trump-russia-investigation-putin.html [https://perma.cc/5L7A-78VU].

340. Trump Lashes Out at Whistleblower and Renews Attack on House Intelligence Chair, THE GUARDIAN (Sept. 30, 2019), https://www.theguardian.com/us-news/2019/sep/30/donald-trump-hasput-whistleblower-in-danger-lawyers-say-ukraine-impeachment [https://perma.cc/DYS6-VMVL]. (Though Trump seemed to imply that traitors were historically executed as a regular practice, readers of this article are aware that Americans executions for treason have been quite rare.) Previously, Trump had responded to the publication of an anonymous op-ed by a cabinet official by writing, "TREASON?" on Twitter. Trump Accuses Aide of Treason for Anonymous New York Times op-ed, Vox.coм (Sept. 5, 2018), https:/www.vox.com/2018/9/5/17825062/new-york-timestrump-op-ed-treason [https://perma.cc/PKU2-E9DP].

341. See Baze v. Rees, 553 U.S. 35 (2008) (Thomas, J. concurring).

342. See generally Wilson, supra note 16.

343. Rahman, supra note 274. 
The other potential reason to bring a treason charge is the moral opprobrium that accompanies what Blackstone deemed to be "the highest crime." This is the sense in which Henry Mark Holzer argued that the government's failure to indict Taliban-volunteer John Walker Lindh a "colossal mistake" because he did not face the consequences of "betraying [his] country and its people." ${ }^{344}$ But there are problems with this analysis as well. As discussed above, many treason convictions generated public sympathy rather than opprobrium. ${ }^{345}$ At the same time, many who have not been indicted for treason nonetheless have been colloquially labeled as "traitors." Edward Snowden is perhaps the latest example, having been labeled a traitor by former Vice President Dick Cheney, Senator Dianne Feinstein, former House Speaker Newt Gingrich, Washington Post columnist Roger Cohen, and others. ${ }^{346}$ Before Snowden, it was Chelsea Manning, ${ }^{347}$ and before her, Jane Fonda. ${ }^{348}$ Politicians and non-academic commentators rarely make a principled distinction between the formal charge of treason and other crimes of disloyalty.

Should treason thus be consigned to historical discussion alone? On the contrary, the history of the American treason charge outlined above suggests that treason jurisprudence should be revitalized. For both constitutional and sociological reasons, the treason charge has generally proven to be resistant to abuse and misuse, while the Espionage Act and other disloyalty charges have not. And even where the charge has been misused by prosecutors, such as during the labor treason cases, the public recognized the improper use of the weighty charge and brought pressure on the government, causing many charges to be dropped. The same scrutiny has not always accompanied other disloyalty offenses. The trend of replacing treason with lesser offenses is most visible at the federal level, but it can be observed at the state level as well. New York, one of the few states

344. Henry Mark Holzer, Why Not Call it Treason?: From Korea to Afghanistan, 29 S.U. L. REV. 181, 221-22 (2002); but see Suzanne Kelly Bapp, Fear and Loathing in America: Application of Treason Law in Times of National Crisis and the Case of John Walker Lindh. 54 Hastings L.J. 1721 (2003).

345. As discussed above, Dorr's conviction led to the election of a candidate who pledged to "liberate" him. John Brown became a martyr to the abolitionist cause. The backlash against the treason indictments for Homestead strikers forced the state to abandon the charges.

346. Mary-Rose Papandrea, Leaker Traitor Whistleblower Spy: National Security Leaks and the First Amendment, 94 B.U.L. REV. 449, n.200 (2014); J. Richard Broughton, The Snowden Affair and the Limits of American Treason, 3 L.M.U. L. REV. 5, 6-7 (2015).

347. In a military trial for "aiding the enemy" (an offense under military justice related to treason), Manning's prosecutor referred to her as "a traitor, a traitor who understood the value of compromised information in the hands of the enemy and took deliberate steps to ensure that they, along with the world, received it." Id. Manning would be acquitted of the charge. Charlie Savage, In Closing Argument, Prosecutor Casts Soldier as 'Anarchist' for Leaking Archives, N.Y. TIMES (July 25, 2013), https://www.nytimes.com/2013/07/26/us/politics/closing-arguments-due-inmanning-leaks-case.html [https://perma.cc/89R2-N2XB].

348. See generally, Henry Mark Holzer and Erika Holzer, "AID AND COMFORT”: JANE FOndA IN NoRTH VietNAM (2002), a book-length argument by Holzer that Fonda was guilty of treason. 
without a modern treason provision, continuous to criminalize conduct analogous to treason as criminal anarchy. ${ }^{349}$

Acts of criminal disloyalty by Americans who unambiguously owe allegiance to the federal and state governments should primarily be viewed through the lens of treason law. Granted, multiple courts of appeal have considered and rejected the argument that the Espionage Act is unconstitutional because it relates to treason without complying with the Treason Clause. ${ }^{350}$ But regardless of whether those cases were correctly decided, they do not prohibit a re-prioritization of treason prosecutions. ${ }^{351}$ On occasion, the heightened standards imposed by treason law will lead to acquittals, as they did in the cases of Aaron Burr, various Philippine insurgents, and Cramer. Likewise, public skepticism about whether treason is truly an appropriate charge may lead to charges being dropped or sentences being commuted, as it did in several of the labor treason cases. These outcomes were anticipated by the framers of the Treason Clause and were seen as laudable safeguards of liberty. Indeed, it is precisely when prosecutors have been afforded ways of making the treason charge redundant that misuse has abounded, such as during the World War I dissent cases.

\section{Incorporation of the Treason Rights Through the Fourteenth Amendment}

But if treason law is to be revitalized, a doctrinal change is warranted. The distinction between state and federal treason law reflects the original federal structure. This structure was irrevocably altered by the Civil War and the Fourteenth Amendment, which provided in part that:

No State shall make or enforce any law which shall abridge the privileges or immunities of citizens of the United States; nor shall any State deprive any person of life, liberty, or property, without due process of law; nor deny to any person within its jurisdiction the equal protection of the laws.

The meaning of this passage "divided [the] Court for many years." ${ }^{352}$ It sparked a century-long legal debate about the extent to which it incorporated various constitutional rights, most significantly the Bill of Rights but also the Writ of Habeas Corpus, against the states. ${ }^{353}$

The most natural means for incorporation of the Bill of Rights was the

349. N.Y. PENAL LAW $\S 240.15$.

350. See United States v. Kim, 808 F. Supp. 2d 44, $48-50$ (D.C. Cir. 2011); Wimmer v. United States, 264 F. 11, 12 (6th Cir 1920). Even if these cases are correctly decided, they do not necessarily foreclose the argument that lesser disloyalty charges should be accompanied only by lesser penalties, and that the steepest penalties may not be applied without the protections that accompany the most severe disloyalty crime.

351. Holzer, supra note 344, at 185 (arguing that post-WWII Espionage Act cases could have been brought at treason cases).

352. McDonald v. Chicago, 561 U.S. 742 (2010) (Thomas, J., concurring).

353. Akhil Reed Amar, The Bill of Rights and the Fourteenth Amendment. 101 YALE L.J. $1193,1218-1260$ (1992). 
amendment's Privileges or Immunities Clause, but this was foreclosed by the Supreme Court's decision in the Slaughter-House Cases. ${ }^{354}$ That decision, just five years after ratification of the Fourteenth Amendment, limited the Privileges or Immunities Clause merely to those rights which "owe their existence to the Federal government, its National character, its Constitution, or its laws." ${ }^{355}$

In theory, this might have left room for the clause to protect certain rights enumerated in the Constitution-including the rights of those accused of treason-from state infringement. But the Court went on to narrow the scope of the clause even more drastically in the dubious United States v. Cruikshank ${ }^{356}$ decision, where it held that the right to assemble under the First Amendment and the right to bear arms under the Second Amendment were not incorporated through the Privileges or Immunities Clause because both rights pre-existed the Constitution and did not depend on it for their existence. ${ }^{357}$ This left only a handful of rights which did not pre-exist the Constitution, such as the right to travel, ${ }^{358}$ within the scope of the clause. The rights codified in the Treason Clause, which date to Fourteenth Century English law, clearly do not follow within its scope under Cruikshank.

Over time, the Supreme Court embraced the view that fundamental rights that are essential to the American "scheme of ordered liberty" and "deeply rooted" in the nation's history and tradition are incorporated by the Due Process Clause of the Fourteenth Amendment. ${ }^{359}$ While there is genuine logical tension between the incorporation of substantive rights through a clause dealing with procedure, this proved the lesser evil compared to the late-Nineteenth Century Court's disregard of the clear intention of the amendment's framers to incorporate the Bill of Rights somewhere within the amendment. ${ }^{360}$ Virtually all of the rights established in the first eight amendments have now been incorporated, and the Due Process Clause has been held to incorporate against the states other rights not explicitly outlined in the Bill of Rights. ${ }^{361}$ An unanswered but frequently debated question is whether it also incorporates the right to a federal habeas forum. ${ }^{362}$

354. See The Slaughterhouse Cases, 83 U.S. 36 (1873).

355. Id. at 79 .

356. United States v. Cruikshank, 92 U.S. 542 (1876).

357. Id. at 551-53; see also McDonald (Thomas, J., concurring).

358. Saenz v. Roe, 526 U.S. 489, 503 (1999).

359. See 561 U.S. 74 (2010).

360. Amar, supra note 353.

361. See Lawrence v. Texas, 339 U.S. 558, 562 (2003) (Due Process Clause protects "liberty of the person both in its spatial and in its more transcendent dimensions"); Roe v. Wade, 410 U.S. 113 (1973); Allgeyer v. Louisiana, 165 U.S. 578 (1897) (Fourteenth Amendment guarantees freedom "to pursue any livelihood or avocation"); but see ROBERT H. BORK, THE TEMPTING OF America: The Political Seduction of the Law 236 (1990) (arguing that only the Bill of Rights is incorporated by the Fourteenth Amendment, and it was otherwise "entirely a procedural guarantee").

362. See Lee Kovarsky, Prisoners and Habeas Privileges Under the Fourteenth Amendment, 67 VAND. L. REV. 609, 611-12 (2014) (“The U.S. Reports contain no answer to a million-dollar 
As we have seen, the framers of the Constitution created a set of rights for anyone accused of treason by the new government. First, the offense cannot be expanded, either by Congress or judicial interpretation, beyond levying war or adhering to the enemies of the United States, giving them aid and comfort. Second, the accused possesses a unique procedural right, the requirement of two witnesses to testify to the same overt act in open court. Finally, one potential punishment, "corruption of blood," was abolished. This set of rights is deeply rooted in the nation's history; indeed, they were an expansion of rights provided under English law that date back to the Treason Act of 1351 and the Treason Trials Act of 1688 .

We have also seen how these rights should be viewed as essential to the American scheme of ordered liberty. Spurious treason prosecutions were a core concern of the nation's founders, and they carefully designed the Treason Clause to preserve liberty by addressing that concern. To the extent that the clause does not come to mind when a modern observer reflects on the critical provisions of the Constitution, it is arguably because the clause has been so successful at its intended purpose. Because of the Treason Clause, attempts to suppress dissent through the prosecution of disloyalty have been carried out through other means such as the Espionage Act, and the resulting battles have been fought over the meaning of the First Amendment rather than of the Treason Clause. But we should not mistake the scarcity of controversial treason prosecutions for insignificance.

Incorporation of the Treason Clause would impact the states in three practical ways. First, it would restrict states from prosecuting types of treason that were rejected by the clause's framers. To date, the Virginia Constitution continues to define treason against the Commonwealth as broader than federal treason, encompassing resistance against the execution of Virginia's laws among other actions. Vermont also defines treason as including treasonous conspiracies, contrary to federal law. Incorporation would prevent prosecutions under these expansive treason statutes, and it would clearly disallow any judicial interpretation of any state treason clause or statute that extended beyond federal law.

Second, incorporation would impact those few states, including New York, that no longer explicitly criminalize treason; the New York constitution's only mention of treason is a restriction of the governor's ability to pardon the crime. Yet, New York did not so much abolish the state treason offense as replace it with the crime of "criminal anarchy." "363 An incorporated treason right would provide a defendant accused of that offense with the argument that any prosecution against them that the charge was de facto a treason prosecution and required two

question: Are state prisoners constitutionally entitled to a federal habeas forum to contest their custody? . . . The strongest existing argument . . . involves a theory of incorporation under the Fourteenth Amendment's Due Process Clause."); see generally Jordan Steiker, Incorporating the Suspension Clause: Is There a Constitutional Right to Federal Habeas Corpus for State Prisoners, 92 Mich. L. REV. 862, 868 (1994).

363. See N.Y. Penal Law $\S 240.15$. 
witnesses to the same overt act.

Finally, incorporation would ensure that the evidentiary requirement of two witnesses to the same overt act is applied in all treason prosecutions. Of course, most state constitutions and treason statutes already include this requirement. But other rights that have been incorporated through the Fourteenth Amendment, such as the Second Amendment's right to bear arms, ${ }^{364}$ was paralleled by near-identical analogues in many state constitutions. ${ }^{365}$ The fact that a right has largely been enshrined at the state level is not an argument against incorporation, and the evidentiary requirement for treason convictions warrants incorporation.

A slight variant on this argument is that the treason rights are privileges and immunities protected by the Fourteenth Amendment, rather than a component of substantive due process guaranteed by that amendment. This would accord with Justice Thomas's concurrence in McDonald, which argued for a revitalization of the Privileges or Immunities Clause rather than expansion of the Due Process Clause. ${ }^{366}$ But despite the counter-intuitive nature of substantive due process, the treason rights are a better fit for that clause than for the Privileges or Immunities Clause. First, unlike many other substantive rights incorporated through the Due Process Clause, the treason rights do have a procedural element: the two-witness requirement. Second, and more importantly, the Due Process Clause applies to "any person," whereas the Privileges or Immunities Clause applies to "citizens of the United States." As we have seen, treason prosecutions turn on allegiance, not citizenship, and the treason rights apply in all such prosecutions - even of those who are not citizens. Incorporation through the Due Process Clause thus seems the better outcome.

\section{CONCLUSION}

The centrality of the Treason Clause in modern constitutional jurisprudence appears diminished at first glance. But the treason charge has at times assumed great importance after extended periods of dormancy. In an age when concerns about national security and accusations of disloyalty have grown increasingly prevalent, a revitalization of the law of treason is in order. The legal and normative restrictions around the law of treason have largely served the dual purposes of protecting the rights of the accused while safeguarding the state against grave betrayal. Incorporation of the Treason Clause would have a meaningful, if contained, impact. Moreover, the conclusion that the Treason Clause merits incorporation should inform our assessment of other rights set forth in the pre-1866 Constitution, including the right to a federal habeas forum, that may warrant formal incorporation against the states.

364. McDonald v. City of Chicago, 561 U.S. 742, 770-78 (2010).

365. See Alexander Gouzoules, The Diverging Right(s) to Bear Arms: Private Armament and the Second and Fourteenth Amendments in Historical Context, 10 ALA. C.R. \& C.L. L. REV. 159, 192 (2019).

366. See McDonald v. City of Chicago, 561 U.S. 742, 806-58 (2010) (Thomas, J., concurring). 